Shlepr, K. R., R. A. Ronconi, B. Hayden, K. A. Allard, and A. W. Diamond. 2021. Estimating the relative use of anthropogenic resources by Herring Gull (Larus argentatus) in the Bay of Fundy, Canada. Avian Conservation and Ecology 16(1):2. https://doi.org/10.5751/ACE-01739-160102 Copyright $(C 2021$ by the author(s). Published here under license by the Resilience Alliance.

Research Paper

\title{
Estimating the relative use of anthropogenic resources by Herring Gull (Larus argentatus) in the Bay of Fundy, Canada
}

\author{
Katherine R. Shlepr ${ }^{1,2}$, Robert A. Ronconi ${ }^{3}$, Brian Hayden ${ }^{4}$, Karel A. Allard ${ }^{3}$ and Antony W. Diamond ${ }^{1}$ \\ ${ }^{1}$ Atlantic Lab for Avian Research, University of New Brunswick, ${ }^{2}$ Avian Ecology Lab, Florida Atlantic University, ${ }^{3}$ Canadian \\ Wildlife Service, Environment and Climate Change Canada, ${ }^{4}$ Canadian Rivers Institute, University of New Brunswick
}

\begin{abstract}
Gulls (Larus spp.) are described as generalist, opportunistic feeders that show great flexibility in habitat use. Despite an apparent advantage in changing landscapes, many Larus populations have declined in eastern North America since the 1990s. The main hypothesis explaining gull declines at a broad scale is a decrease in total food availability, especially anthropogenically derived fisheries discards and human refuse as industries and cities have improved their management practices. However, it is difficult to quantify the total proportion of gull diet subsidized by humans to test this hypothesis because many common prey items can be traced to both anthropogenic and nonanthropogenic sources. Our aim was to estimate the proportion of diet derived from anthropogenic food sources for Herring Gull (L. argentatus) during the breeding season at the two largest colonies in the Bay of Fundy, Canada, which are located $36 \mathrm{~km}$ apart. GPS loggers were deployed to quantify spatiotemporal movement patterns, and whole blood and feather samples were collected for $\delta^{13} \mathrm{C}$ and $\delta^{15} \mathrm{~N}$ stable-isotope analysis to estimate diet composition during the incubation and chick-rearing stages of the breeding season. Results indicate that there is spatial segregation in the foraging areas used by gulls from the two colonies. All gulls relied on a variety of anthropogenic food sources, with some individuals selecting heavily on fisheries (i.e., active town wharfs, fish packaging plants, aquaculture pens) and mink (Neovison vison) fur farms. Landfills were not a significant source of food during the breeding season. Our study provides valuable information about the relative reliance of gulls on anthropogenic food subsidies, providing insight into how changing industry practices may affect patterns in nesting and foraging by gulls in the region.
\end{abstract}

\section{Estimation de l'utilisation relative de ressources anthropiques par le Goéland argenté (Larus argentatus) dans la baie de Fundy, Canada}

RÉSUMÉ. Les goélands (Larus spp.) sont décrits comme des mangeurs généralistes et opportunistes qui font preuve d'une grande souplesse dans l'utilisation de leur habitat. Malgré un certain avantage procuré par la modification des paysages, de nombreuses populations de Larus ont diminué dans l'est de l'Amérique du Nord depuis les années 1990. La principale hypothèse derrière cette diminution à grande échelle serait la baisse de la disponibilité générale de nourriture, en particulier de rejets de pêche d'origine anthropique et de déchets d'origine humaine, les industries et les villes ayant amélioré leurs pratiques de gestion. Cependant, il est difficile de quantifier la proportion totale du régime alimentaire des goélands fournie par l'homme pour tester cette hypothèse, car de nombreuses proies communes peuvent provenir à la fois de sources anthropiques ou non anthropiques. Notre objectif était de calculer la proportion du régime alimentaire provenant de sources anthropiques chez le Goéland argenté (L. argentatus) pendant la saison de reproduction dans les deux plus grandes colonies de la baie de Fundy, au Canada, qui sont situées à $36 \mathrm{~km}$ l'une de l'autre. Nous avons déployé des enregistreurs GPS pour quantifier l'ensemble des déplacements spatiotemporels, et pris des échantillons de sang entier et de plumes pour faire l'analyse des isotopes stables $\delta 13 \mathrm{C}$ et $\delta 15 \mathrm{~N}$ afin d'estimer la composition du régime alimentaire pendant les étapes d'incubation et d'élevage des poussins. Nos résultats indiquent qu'il y a une ségrégation spatiale dans les zones d'alimentation utilisées par les goélands des deux colonies. Tous les goélands dépendaient d'une variété de ressources alimentaires anthropiques, certains individus se nourrissant principalement des produits d'activités de pêcheries (c.-à-d. aux quais municipaux actifs, aux usines de transformation des poissons, aux bassins d'aquaculture) et aux élevages de visons (Neovison vison). Les dépotoirs n'étaient pas une source importante de nourriture pendant la saison de reproduction. Notre étude fait état d'informations précieuses sur la dépendance relative des goélands aux ressources alimentaires d'origine anthropique, et révèle comment l'évolution des pratiques industrielles peut affecter les habitudes de nidification et de recherche de nourriture des goélands dans la région.

Key Words: diet; ecosystem-based management; foraging; GPS tracking; habitat use; nuisance species; population decline; stable-isotope analysis; urban ecology; wildlife management

\section{INTRODUCTION}

Generally, migratory birds are of conservation interest because of the essential roles they play in ecosystems, their cultural appeal and symbolic importance, and because population declines have been observed on local to global scales (Cury et al. 2011, Rosenberg et al. 2019). Avian species have additionally served as indicators of ecosystem health in conservation and restoration projects worldwide (Weseloh et al. 2002, Frederick et al. 2009, 
Scopel et al. 2018, Velarde et al. 2019). Despite these values, gulls (Larus spp.) are something of an outlier, often labeled as a "nuisance" to human health and industry (Blokpoel and Tessier 1986, Cleary et al. 2006, Clark et al. 2013, Province of New Brunswick 2013) as well as a threat to other species of conservation (e.g., terns, salmon) and social or economic (e.g., eiders) interest (Donehower and Bird 2008, Frechette et al. 2015, LaRue 2016, Scopel and Diamond 2017). Nuisance concerns about gulls have caused the focus of wildlife management to shift away from mitigation of human practices that are incompatible with the maintenance of ecological integrity to the control of gulls. Wildlife managers may consider mitigating both the causes and symptoms of apparent nuisance situations created by wildlife, but feasibility and perceived simplicity often favor strategies directed at the symptoms. This approach may lead to a commitment to the inefficient allocation of limited conservation resources because the causes of environmental imbalance are not addressed.

Long-term monitoring indicates that some of the most common North American Larus species have declined asynchronously throughout North America since the 1990s or earlier (Nisbet et al. 2013, Bond et al. 2016, Mittelhauser et al. 2016, Wilhelm et al. 2016) despite their reportedly flexible foraging habits and habitat use (Pierotti and Annett 1991, Nisbet et al. 2017). The family Laridae, which includes both gulls and terns, has declined in abundance in North America by 50.5\% (90\% confidence interval: 39.9-58.4\%) between 1970 and 2017, with 16 of 22 of Laridae species having negative trends, including Herring Gull (L. argentatus) and Great Black-backed Gull (L. marinus; Rosenberg et al. 2019). Although rooftop nesting, which may be missed by traditional coastal seabird surveys, might account for some of this reported decline, past surveys that include urban areas generally report the proportion of rooftop nests to be < $15 \%$ of all nests (Dwyer et al. 1996, Raven and Coulson 1997, Nager and O'Hanlon 2016, Blight et al. 2019). Therefore, a potential increase in rooftop nesting is insufficient to explain the reported pattern of long-term continental population declines. Overall, these declines suggest that research should focus on the drivers and related pressures on ecosystems and ecosystem processes resulting from human activities rather than on the species-level interactions and impacts. Ecosystem-based management will require a shift to more integrated and comprehensive management approaches to mitigate anthropogenic contributing factors to threats.

Despite the general complexity of predicting the species-specific outcomes of interacting biotic and abiotic factors, diet is understood to be an important driver in gull population dynamics (Anderson et al. 2016, Bennett et al. 2017, Juvaste et al. 2017). In particular, the population-level implications of the use of open landfills (Kadlec and Drury 1968, Coulson 2015, Ackerman et al. 2018, Seif et al. 2018) and fisheries discards (Annett and Pierotti 1999, Wilhelm et al. 2016, Bennett et al. 2017, Foster et al. 2017) by gulls have long been debated, especially regarding the extent to which these food subsidies contributed to the increase in gull numbers in the early 20th century (Drury and Kadlec 1974). Nevertheless, major shifts in diet since the 1990s have been recorded in Larus spp. These shifts include a switch from wildcaught prey to novel anthropogenic food sources (Hobson et al.
2015, Osterback et al. 2015, Ramírez et al. 2015, Bond 2016) and from marine prey to terrestrial-sourced foods (Blight et al. 2015, Bond 2016, Ackerman et al. 2018, Maynard and Ronconi 2018) or lower trophic-level marine prey species (Farmer and Leonard 2011, Ronconi et al. 2014). Importantly, studies in the latter group do not systematically capture whether diet items are from anthropogenic or nonanthropogenic sources.

The number of rooftop-nesting gulls has grown in Europe (Spelt et al. 2019) and may be growing in North America (Perlut et al. 2016, Kroc 2018), suggesting that gulls are increasingly interacting with humans. This growing overlap, especially at a time when gull numbers are declining overall, heightens the need to understand how prey selection and availability influence gull distribution and population dynamics. This overlap is particularly true of industries that may inadvertently supply prey to gulls or reduce natural prey abundance or availability, especially when industries have options to mitigate such practices. Anthropogenic sources of prey commonly include fishing, agricultural, and waste management industries. In the fishing industry, harvesting, processing, and packaging activities produce bycatch, bait, and waste that become available to gulls when discarded at sea. Likewise, gulls have been known to glean crop fields and access uncontained waste from animal husbandry operations. Agricultural activities such as field tilling and fertilizer application also enhance the availability of naturally occurring prey, including soil-dwelling invertebrates. Finally, the waste management industry, including landfills, transfer stations, and composting facilities, imperfectly contains its product during operations.

The effect of anthropogenic food availability on Larus spp. prey selection has been investigated using stable isotope analysis since Hobson's (1987) work, and modern studies now frequently incorporate GPS tracking with this and other traditional methods of diet description, such as pellet analysis (Steenweg et al. 2011, Ronconi et al. 2014, Enners et al. 2018). One standing challenge is to link prey items to their respective sources, especially in human-affected landscapes. For example, pellet or regurgitate sampling may be used to identify the bones of Atlantic mackerel (Scomber scombrus), but it cannot indicate whether the fish was caught in the wild, scavenged near a wharf, or taken from a fishing vessel at sea (Steenweg et al. 2011, O'Hanlon et al. 2017). Similarly, a fish's trophic level and association with a marine vs. freshwater environment may be inferred using stable isotope analysis, but the point source of those fish remain unknown. GPS tracking allows for detailed analysis of spatiotemporal patterns in travel outside the colony, but cannot be used to confirm which foraging bouts led to successful prey capture. Combining multiple methods to observe foraging behavior is therefore necessary to interpret data about the contribution of anthropogenic food subsidies to bird diet.

Our aim was to quantify the relative use of anthropogenic food sources by breeding Herring Gull in a rapidly changing ecosystem: the Bay of Fundy, Canada. Understanding the contribution of anthropogenic resources to the gull's diet can deepen the understanding of gull-human interactions within an ecosystem context and may help to uncover the role that human activities play in gull distribution and population dynamics. 


\section{METHODS}

\section{Study area}

The Gulf of Maine/Bay of Fundy system (Fig. 1) has large, shallow areas uniquely influenced by strong tidal currents and coastal inputs, producing one of the world's richest and most diverse marine biota (Parker 2012). From 2005 to 2015, sea surface temperatures in the Gulf of Maine warmed faster than $99.9 \%$ of the global ocean (Pershing et al. 2015). This warming, combined with a highly intensive fishing industry, has caused widespread changes to the entire marine food web, from phytoplankton to top predators such as cod (Gadus morhua; Pershing et al. 2015). As highly visible top predators, marine-dependent seabirds such as terns (Sterna spp.) and Atlantic Puffin (Fratercula arctica) have been used as biological indicators to monitor bottom-up changes occurring in the Gulf of Maine (Diamond and Devlin 2003, Gaston et al. 2009). Because gulls are unique among seabirds in their success in accessing terrestrial resources, changes in measures such as reproductive success and adult survival are likely to lag in gulls compared to other marine-dependent indicator species. However, a rapid, extreme shift in food resources should be reflected quickly in studies of gull diet and foraging movements and, ultimately, may be detected as local or regional declining nest numbers if gulls do not compensate for the ecosystem changes.

Fig. 1. Breeding season locations of Herring Gull (Larus argentatus) captured on nests on Kent Island, New Brunswick, Canada, and and Brier Island, Nova Scotia, Canada. Kent Island: white triangle = colony, blue points = gull locations; $N$ $=11$ individuals that made 2163 off-colony trips, May-July 2015-2016. Brier Island: white star = colony; pink points $=$ gull locations; $N=16$ individuals that made 2092 off-colony trips, May-July 2014-2016. The GPS data set was filtered to include only off-colony locations ( $>500 \mathrm{~m}$ from an individual's nest) where speed was $<2 \mathrm{~km} / \mathrm{h}$ to target foraging and roosting destinations.

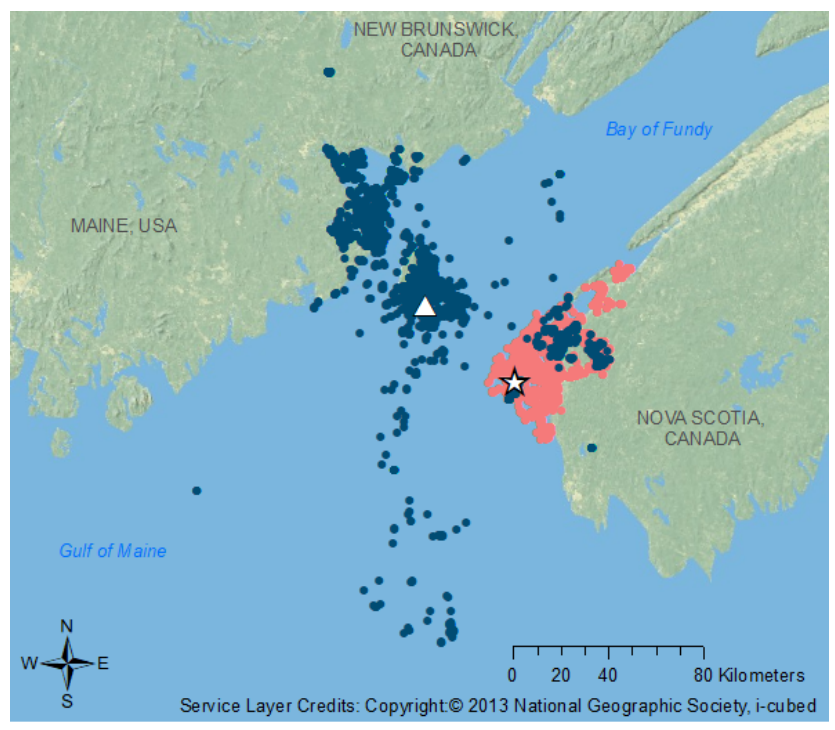

Kent Island, New Brunswick, Canada $\left(44.581^{\circ} \mathrm{N}, 66.756^{\circ} \mathrm{W}\right)$ was the largest Herring Gull colony in the Gulf of Maine/Bay of Fundy in the 1930s-1940s, with a population > 20,000 pairs, and probably served as a source for new colonization by gulls to the east and south during that period (Cannell and Maddox 1983). By 1983, the colony declined to 5000 nesting pairs, and then declined further to 1400 by 1989 , possibly because of egg collection by local hunters (Hébert 1989). The latest estimates of approximately 6000 pairs in 2001 (Ronconi and Wong 2003) and approximately 3000 pairs in 2015 (Bennett et al. 2017) show that the population rebounded slightly after Hébert's (1989) study but may be declining again (Wilhelm et al. 2016). By contrast, nesting habitat on Brier Island, Nova Scotia, Canada $\left(44.275^{\circ} \mathrm{N}, 66.345^{\circ}\right.$ W) became available only after drainage of the island's bog in 1958. Herring Gull and Great Black-backed Gull colonized Brier Island thereafter, and the number of nesting pairs grew from 0 in 1970 to $>2400$ by 2013 (Toms 2015). At a total colony size of 5100 breeding pairs, Brier Island was the largest Herring Gull colony in Atlantic Canada in 2016. Kent Island and Brier Island are located $36 \mathrm{~km}$ apart, so there could be high spatial overlap in the foraging areas around each colony (Drury and Nisbet 1972, Thaxter et al. 2012).

Fieldwork was conducted during the breeding season (MayAugust) on Kent Island in 2015 and on Brier Island in 2014-2015 (Fig. 1). Adults were captured during incubation on nests containing three-egg clutches using walk-in traps. Basic morphometric measurements were taken to determine the sex of sampled individuals according to the discriminant function developed by Robertson et al. (2016). An 80- $\mu \mathrm{L}$ sample of blood was drawn from the tarsal or brachial vein of captured individuals, and the distal $3 \mathrm{~cm}$ from the oldest feather among the innermost primaries, P1-P3, was clipped (the significance of these specific samples is described below; Steenweg et al. 2011). On a subset of birds sampled for stable isotopes, GPS loggers were deployed using a leg-loop harness made of Teflon ribbon following Mallory and Gilbert (2008). Two logger types were used, including batterypowered i-GotU (MobileAction Technology, 17-g logger with waterproofing + 2-g harness, $N=15$, Brier Island only) and solarpowered HARRIER-L (Ecotone Telemetry, 15-g logger + 2-g harness, $N=26$, both islands). Loggers were programmed to record speed and latitude-longitude coordinates at intervals of 5 or $15 \mathrm{~min}$ for i-GotU and Ecotone loggers, respectively. For birds equipped with i-GotU loggers, recapture was attempted for data retrieval approximately $2 \mathrm{wk}$ after logger deployment. No recapture was attempted (or required) at nests where the bird carried a solar-powered logger; instead, a long-range antenna was placed at the edge of both colonies to receive GPS data remotely from tagged gulls. We returned to each colony briefly in 2016 to set up a long-range antenna to collect GPS data from any previously tagged gulls returning to the colonies.

\section{Analysis of prey sources using GPS data}

In total, 11 solar-powered and 5 battery-powered GPS loggers contributed data from Brier Island, Nova Scotia, and 11 solarpowered loggers contributed data from Kent Island, New Brunswick (Table 1; Appendix 1 Table). Results from a discriminant function of morphometric measurements (Robertson et al. 2016) suggested that 14 of the tagged individuals were female, 11 were male, and 2 could not be determined. To 
annotate the GPS records with breeding stage categories, average hatch dates were calculated for both colonies based on nest monitoring data (2015) and observations made regarding nesting activity while trapping (e.g., average clutch size, frequency of hatching; 2014-2015). Average hatch dates were then used to establish incubation periods (beginning $6 \mathrm{wk}$ prior to average colony hatch) and chick rearing periods (ending $6 \mathrm{wk}$ after average colony hatch) in each year for each colony.

Table 1. Number of breeding Herrings Gull (Larus argentatus) tracked with GPS tags and/or sampled for stable-isotope analysis from colonies in the Bay of Fundy, Canada, 2014-2016. Months specified in each column heading indicate which time-period the prey source (GPS analysis) or prey type (stable-isotope analysis) samples represent.

\begin{tabular}{|c|c|c|c|c|c|}
\hline \multirow[b]{2}{*}{ Colony } & \multirow[b]{2}{*}{ Year } & \multicolumn{2}{|c|}{ GPS analysis } & \multicolumn{2}{|c|}{ Stable-isotope analysis } \\
\hline & & $\begin{array}{l}\text { Incubation } \\
\text { (May-June) }\end{array}$ & $\begin{array}{c}\text { Chick- } \\
\text { rearing } \\
\text { (Jun-July) }\end{array}$ & $\begin{array}{l}\text { Blood } \\
\text { (May) }\end{array}$ & $\begin{array}{c}\text { Feathers } \\
\text { (May, } 12 \text { mo } \\
\text { prior) }\end{array}$ \\
\hline$\overline{\text { Brier }}$ & 2014 & 14 & 9 & 20 & 48 \\
\hline \multirow[t]{2}{*}{ Island } & 2015 & $9^{\dagger}$ & $6^{*}$ & 36 & 11 \\
\hline & 2016 & $6^{*}$ & $6+$ & 0 & 0 \\
\hline Kent & 2014 & 0 & 0 & 0 & 0 \\
\hline \multirow[t]{2}{*}{ Island } & 2015 & 11 & $11^{\ddagger}$ & 34 & 14 \\
\hline & 2016 & $10^{*}$ & $10^{*}$ & 0 & 0 \\
\hline
\end{tabular}

${ }^{\dagger}$ Includes seven returning individuals that were tagged in 2014.

${ }^{\star}$ All are returning individuals that were tagged in 2014 (Brier Island) or 2015 (Kent Island).

We reviewed raw GPS files to address data collection gaps, duplicate records, and erroneous records (e.g., speed $>100 \mathrm{~km} / \mathrm{h}$ or timestamp outside the deployment period). In years of logger deployment (Brier Island 2014-2015, Kent Island 2015), we excluded GPS records from the first two days of tracking data to avoid analyzing the abnormal sedentary behavior that was observed immediately following gull capture and tagging. Of the loggers we analyzed, no significant long-term effects of capture or tagging on gull movement or productivity were observed during daily nest monitoring visits (Shlepr 2017). Our failure to detect a logger effect is in accordance with previous gull tagging studies with harness attachment (Thaxter et al. 2016, Kavelaars et al. 2018).

Because our aim was to analyze foraging destinations in particular, we developed a filtering protocol to exclude GPS records in the immediate vicinity of the nesting area $(<500 \mathrm{~m}$ from an individual's nest) as well as locations that were likely to have been recorded on the way to or from foraging or roosting destinations. To remove these in-transit points, we assumed that gulls would come to rest at (or near) foraging and roosting destinations, and we filtered the GPS data to retain only records where the GPS logger recorded a speed of $<2.0 \mathrm{~km} / \mathrm{h}$ (Fig. 1). The $2 \mathrm{~km} / \mathrm{h}$ cutoff is equivalent to gull walking speed or slower and is similar to the data-filtering strategy used in previous studies (Shamoun-Baranes et al. 2011, Maynard and Ronconi 2018). We were initially concerned that this decision would bias our results against marine foragers, which are more likely than terrestrial or coastal foragers to fly steadily while foraging because the marine environment is patchy (Weimerskirch 2007) and gulls are visual hunters (Nisbet et al. 2017). However, marine points in our quality-controlled data set were uncommon, and the proportion of points located in the marine environment changed only minimally after filtering the data set for near-stationary records (14.2\% of off-colony locations prior to filtering for speeds $<2$ $\mathrm{km} / \mathrm{h} ; 9.2 \%$ of off-colony locations after filtering for speeds $<2$ $\mathrm{km} / \mathrm{h})$.

Roosting destinations were effectively separated from foraging destinations via identification of known anthropogenic sources of prey using on-ground site observations (in 2015) and GPS results (in 2014-2016). To categorize locally relevant prey sources, polygons of potential point sources of anthropogenic prey items were manually delineated using latitude and longitude coordinates in Google Earth and then entered into R. These categories were: "fisheries" (i.e., active town wharfs, seafood processing and packaging plants, and salmon aquaculture pens), "mink" (i.e., active mink [Neovison vison] farms, where gulls could access mink feed that had fallen through animal cages, and animal composting facilities), and "other" (i.e., active waste transfer stations, solid waste parks, and municipal compost sites). All offcolony GPS records located outside of these "known anthropogenic" polygons defaulted to a category called "unassigned". Unassigned locations represented all nonanthropogenic sources of food, unknown anthropogenic sources of food, and nonforaging roosting locations. To improve explanatory potential for records in the unassigned category, unassigned locations were split into three generic geographic classifications: "terrestrial" (> $3 \mathrm{~km}$ inland), "coastal" ( $\pm 3 \mathrm{~km}$ of shoreline), and "marine" (> $3 \mathrm{~km}$ offshore).

In $\mathrm{R}$, we delineated unique off-colony trips by assigning a trip ID to all GPS records between the time an individual left the vicinity of its nest ( $>500 \mathrm{~m}$ from nest) to the time it reentered its nest area ( $<500 \mathrm{~m}$ from nest). The mean distance from nest for each offcolony trip was calculated and then compared using analysis of variance (ANOVA). Additionally, the proportion of GPS records in known anthropogenic categories was averaged for all available years (2014-2016 Brier Island, 2015-2016 Kent Island) and compared at the colony level using ANOVA. Statistical analyses were conducted using the "aov" package in R ( $\mathrm{R}$ Core Development Team 2019).

\section{Analysis of prey selection using stable isotopes}

Stable isotope blood and feather sample collection followed procedures described in Steenweg et al. (2011). Because wholebody turnover of blood takes approximately $4 \mathrm{wk}$ in birds (Hobson and Clark 1992a), blood samples drawn at the time of trapping reflect the nest building, egg synthesis (females only), and incubation stages of the gull breeding cycle. Additionally, gulls in the Bay of Fundy begin molting their innermost primary feathers during the incubation period (Nisbet et al. 2017). The innermost primaries are synthesized during incubation and are the first to be replaced (i.e., prior to being dropped, the innermost is the oldest feather with a with molt score $=0$ ). Because it was the most consistently available at capture, the tip of the oldest available primary feather was collected for isotope analysis and was assumed to best reflect the individual's diet during the incubation stage one year prior (2013 or 2014 for birds sampled in 2014 and 2015, respectively). Although we were not yet studying prey conditions in the Bay of Fundy in 2013, the oldest primary feather is a useful indicator of local Herring Gull diet because these birds tend to have high interannual site fidelity (Nisbet et 
al. 2017), which was confirmed at our study sites by the high return of gulls that were tagged (Brier Island: six of nine gulls that were present during chick-rearing in 2014 returned to the colony for at least two consecutive years; Kent Island: 10 of 11 gulls that were present during chick-rearing in 2015 returned to the colony in the following year; Table 1; Appendix 1 Table). The mean molt scores recorded for $\mathrm{P} 1$ (the innermost primary feather), $\mathrm{P} 2$, and $\mathrm{P} 3$ were $0.4,0.1$, and 0.0 , respectively $(N=41)$. Finally, potential prey types were determined by local knowledge, our observations of gull foraging from boats (Bay of Fundy) and inland (Nova Scotia, New Brunswick; 2014-2015), and a regionally focused scan of the literature. We sampled these prey types opportunistically throughout the 2015 field season within the reported mean foraging range of gulls by harvesting or obtaining samples from fishers and mink farmers. Terrestrial prey items, including earthworms (Lumbricus spp.), beetles (family Scarabaeidae), and slugs (class Gastropoda), were sampled and analyzed in the lab but were ultimately excluded from isotope mixing models when preliminary results showed that both the $\delta^{13} \mathrm{C}$ and $\delta^{15} \mathrm{~N}$ values of this group were considerably lower than any of the gull tissue samples (mean \pm standard deviation; $\delta^{13} \mathrm{C}:-27.9 \pm 2.5 \% ; \delta^{15} \mathrm{~N}$ : $5.5 \pm 1.7 \%$; see Results for more information).

Whole blood samples $(N=90$; Table 1$)$ were dried in an oven at $60^{\circ} \mathrm{C}$ for $48 \mathrm{~h}$ and then ground by hand using a mortar and pestle. Feathers $(N=73$; Table 1$)$ were cut, washed with a 2:1 chloroform methanol solution to remove surface impurities, and then placed in a $60^{\circ} \mathrm{C}$ oven for 1-2 h to dry. Prey source samples were dried in a $60^{\circ} \mathrm{C}$ oven, ground, and, if relevant, treated with hydrochloric acid (to dissolve carbonate shells) or a 2:1 chloroform methanol solution (to extract lipids). Samples were weighed and submitted to the Stable Isotopes in Nature Laboratory (Fredericton, New Brunswick, Canada) for chemical analysis. Continuous flowisotope ratio mass spectrometry was used for stable-isotope analysis of $\delta^{13} \mathrm{C}$ and $\delta^{15} \mathrm{~N}$. Values were calibrated to International Atomic Energy Agency primary standards: Vienna Pee Dee Belemnite for $\delta^{13} \mathrm{C}$, and atmospheric nitrogen for $\delta^{15} \mathrm{~N}$. Experimental error was determined to be $0.1 \%$ for both isotopes based on repeat analysis of an in-house standard, muskellunge liver tissue (Jardine and Cunjak 2005).

Discrimination factors for whole blood (carbon: $-0.1 \pm 0.7 \%$; nitrogen: $2.8 \pm 0.4 \%$ ) and primary feathers (carbon: $1.2 \pm 0.7 \%$; nitrogen: $4.1 \pm 0.4 \%$ ) were taken from Herring Gull studies by Steenweg et al. (2011) and Ronconi et al. (2014), who averaged the discrimination factors from experiments with Ring-billed Gull (Hobson and Clark 1992b) and other piscivorous seabirds (Bearhop et al. 2002, Cherel et al. 2005, Becker et al. 2007). Potential prey items were analyzed for $\delta^{13} \mathrm{C}$ and $\delta^{15} \mathrm{~N}$ values and then grouped according to isotopic and biological similarity to reduce the number of prey categories considered in mixing models. All statistical analyses were run in $\mathrm{R}$ ( $\mathrm{R}$ Core Development Team 2019). We used ANOVA to test whether year explained any of the variation in $\delta^{13} \mathrm{C}$ and $\delta^{15} \mathrm{~N}$ of gull tissues from Brier Island, where we had two years of sampling (2014 2015), and we also used ANOVA to test whether colony-level differences in $\delta^{13} \mathrm{C}$ and $\delta^{15} \mathrm{~N}$ were significant. Likewise, year and colony were included in the Bayesian mixing model as random and fixed effects, respectively, using the package MixSIAR (Stock et al. 2018).

\section{Estimating anthropogenic resource use with combined methods}

Gulls can obtain some prey from wild and anthropogenic sources, so both aspects (prey source and type) must be known to quantify anthropogenic resource use as a proportion of the whole diet. Because no single method directly measures both aspects, we devised a way to objectively visualize information overlaps between our GPS (prey source) and stable-isotope (prey type) results. We restricted this analysis of anthropogenic resource use to the incubation period because the stable-isotope analysis used tissue samples that only reflect diet in the early stages of breeding.

First, by colony, we used the GPS results (Table 2) to calculate the mean percentage of tagged gull locations that fell into each prey source category (incubation only, all available years). This process provided a snapshot of where gulls tend to spend time foraging. Next, by colony, we used the stable-isotope results to isolate the percentage estimates of prey type by category (blood only, averaged years when available; alternate analysis using feather sample results can be found in Fig. S1 in Appendix 1). This process provided a snapshot of what prey types gulls tend to consume. Finally, to combine this information on where (GPS results) and what (stable-isotope results) gulls tend to eat, we averaged estimates from every ecologically viable combination of prey source categories (GPS results) and prey type categories (stable-isotope results). For example, we averaged the use scores from the logical combination of high trophic marine prey (stableisotope category) in known anthropogenic fisheries sites (GPS category), but we did not average the use scores from the illogical combination of high trophic marine prey (stable-isotope category) in unassigned terrestrial sites (GPS category), labeling illogical prey source-type combinations as such. Even though these wild and anthropogenic resource use values are the result of averaging pairs of percentage estimates, we acknowledge that we do not account for variation around means (standard deviation [SD] in the GPS analysis; 95\% confidence interval [CI] in stableisotope mixing models) by displaying resource use values as unitless scores.

The scores produced by this exercise can be used objectively to weigh the importance of a specific wild or anthropogenic resource relative to other resources available to gulls. These scores theoretically range from $0(0 \%$ mean estimate of a prey source category and $0 \%$ mean estimate of a prey type category) to 100 $(100 \%$ mean estimate of a prey source category and $100 \%$ mean estimate of a prey type category). As such, higher resource use scores indicate that gulls consumed high levels of a prey type that is obtained from a habitat type where gulls spent a lot of time foraging, therefore providing greater confidence that a particular wild or anthropogenic resource is an important part of the gull diet. Conversely, a low resource use score could indicate: (1) a mismatch between the amount of time gulls spent at a habitat type and what they were found to have consumed, which means we have low confidence about the importance of a particular resource; or (2) high confidence that gulls do not depend on a particular resource because associated prey source and prey type estimates were low in both the GPS and stable-isotope analyses. 
Table 2. GPS analysis results showing the percentage (and standard deviation) of GPS locations in each prey source category for Herring Gull (Larus argentatus) captured on nests at Brier Island, Nova Scotia and Kent Island, New Brunswick, Canada. Brier Island: $N=$ 16 individuals that made 2092 off-colony trips, May-July 2014-2016; Kent Island: $N=11$ individuals that made 2163 off-colony trips, May-July 2015-2016. To target foraging and roosting destinations in the analysis, GPS data were filtered to include only off-colony locations where speed was $<2 \mathrm{~km} / \mathrm{h}$. Potential anthropogenic prey sources were defined a priori, and GPS records falling within these polygons were classified as "known anthropogenic" sources. GPS records falling outside anthropogenic source polygons defaulted to an "unassigned" category and were classified as terrestrial ( $>3 \mathrm{~km}$ inland), coastal ( $\pm 3 \mathrm{~km}$ of shoreline), or marine ( $>3 \mathrm{~km}$ offshore). See Table 1 for numbers of birds analyzed.

\begin{tabular}{|c|c|c|c|c|c|c|c|c|c|c|}
\hline \multirow[b]{2}{*}{ Colony } & \multirow[b]{2}{*}{ Year } & \multirow[b]{2}{*}{ Activity } & \multicolumn{4}{|c|}{ Known anthropogenic $(\%)$} & \multicolumn{4}{|c|}{ Unassigned (\%) } \\
\hline & & & Fisheries & Mink & Other & Total & Terrestrial & Coastal & Marine & Total \\
\hline \multirow[t]{6}{*}{ Brier } & \multirow[t]{2}{*}{2014} & Incubation & $15(23)$ & $41(27)$ & $0(0)$ & $57(20)$ & $5(6)$ & $28(13)$ & $9(13)$ & $43(20)$ \\
\hline & & Chick rearing & $25(25)$ & $38(24)$ & $0(0)$ & $63(17)$ & $3(4)$ & $18(15)$ & $15(16)$ & $37(17)$ \\
\hline & \multirow[t]{2}{*}{2015} & Incubation & $26(37)$ & $32(27)$ & $0(0)$ & $59(26)$ & $6(6)$ & $30(20)$ & $4(6)$ & $41(26)$ \\
\hline & & Chick rearing & $19(31)$ & $57(32)$ & $0(0)$ & $76(17)$ & $4(4)$ & $16(15)$ & $4(5)$ & $24(17)$ \\
\hline & \multirow[t]{2}{*}{2016} & Incubation & $27(27)$ & $39(30)$ & $0(0)$ & $66(17)$ & $7(9)$ & 25 (19) & $2(3)$ & 34 (17) \\
\hline & & Chick rearing & $23(33)$ & $52(31)$ & $0(0)$ & 75 (16) & $4(3)$ & $20(16)$ & $1(2)$ & $26(16)$ \\
\hline \multicolumn{3}{|c|}{ Brier Island colony average } & $22(28)$ & $42(27)$ & $0(0)$ & $64(20)$ & $5(6)$ & $24(16)$ & 7 (11) & $36(20)$ \\
\hline \multirow[t]{4}{*}{ Kent } & \multirow[t]{2}{*}{2015} & Incubation & $24(26)$ & $4(13)$ & $1(1)$ & $28(25)$ & $0(1)$ & $66(22)$ & $6(7)$ & $72(25)$ \\
\hline & & Chick rearing & $23(21)$ & $6(12)$ & $0(0)$ & $29(21)$ & $2(7)$ & $56(22)$ & $13(19)$ & $71(21)$ \\
\hline & \multirow[t]{2}{*}{2016} & Incubation & $31(25)$ & $4(13)$ & $1(1)$ & 37 (24) & $2(4)$ & $59(25)$ & $3(4)$ & $63(24)$ \\
\hline & & Chick rearing & $36(29)$ & $7(22)$ & $3(4)$ & $46(26)$ & $0(0)$ & 49 (23) & $5(11)$ & $54(26)$ \\
\hline \multicolumn{3}{|c|}{ Kent Island colony average } & $28(25)$ & $5(15)$ & $1(2)$ & $35(24)$ & $1(4)$ & $58(23)$ & $7(12)$ & $65(24)$ \\
\hline
\end{tabular}

\section{RESULTS}

Of the 115,723 GPS fixes recorded during the incubation and chick-rearing periods, 51,425 (44\%) were recorded during 4255 independent off-colony trips at speeds $<2 \mathrm{~km} / \mathrm{h}$; these were the data used in subsequent analyses. These data came from 16 individuals from Brier Island $(N=11$ solar loggers, mean $\pm \mathrm{SD}$ : $124 \pm 81 \mathrm{~d} /$ bird tracked, 2014-2016; $N=5$ battery loggers, mean \pm SD: $19 \pm 5 \mathrm{~d} /$ bird tracked, 2014 incubation only) and 11 individuals from Kent Island $(N=11$ solar loggers, mean \pm SD: $113 \pm 30 \mathrm{~d}$ /bird tracked, 2015-2016; Table S1 in Appendix 1). For the stable-isotope analysis, we collected blood and feather samples from all tagged individuals and additional captures at both colonies (Table 1).

\section{Analysis of prey sources using GPS data}

Gulls from Brier Island tended to travel further away from their colony $(N=16$, mean \pm SD: $38 \pm 81 \mathrm{~km})$ than gulls from Kent Island $(N=11$, mean \pm SD: $21 \pm 24 \mathrm{~km}$; ANOVA $P<0.001$; Fig. 1 ). Brier Island gulls spent a range of $15-85 \%$ (mean \pm SD: 64 $\pm 20 \%$ ) of their off-colony time at rest in a known anthropogenic site, which is significantly more than Kent Island gulls, which spent a range of $3-82 \%$ (mean \pm SD: $35 \pm 24 \%$ ) of their time in the same category (ANOVA $P=0.016$; Table 2). For gulls of both colonies, most GPS points that were located outside a known anthropogenic site occurred in coastal ( $\pm 3 \mathrm{~km}$ from shoreline) habitat (Brier Island: $24 \pm 16 \%$, Kent Island: $58 \pm 23 \%$ ), which may reflect intertidal foraging or time spent roosting without foraging. Gulls overall spent little time foraging or resting in the marine environment (Brier Island: $7 \pm 11 \%$, Kent Island: $7 \pm 12 \%$; Fig. 1, Table 2).

As is reflected by the large standard deviations in the known anthropogenic site category (Table 2), individual use of known anthropogenic sites varied widely, especially among gulls from Kent Island (Fig. 2). The use of fisheries (including town wharfs, fish processing plants, and salmon aquaculture rings) varied widely among individuals and could not be explained by colony of origin (ANOVA $P=0.272$; Fig. 2). Conversely, individuals appeared to use mink prey sources either heavily or not at all. Colony appeared to be the biggest determinant for this food source; 11 of 16 gulls from Brier Island spent at least $25 \%$ of their off-colony time at mink sites compared to 1 of 11 Kent Island gulls (ANOVA $P<0.001$; Fig. 2). Only three gulls (all from Kent Island) ever visited an alternative anthropogenic site (including municipal and regional landfills), and that site type (i.e., other) constituted $\leq 4 \%$ of records for each of the three individuals. Overall, visits to municipal or regional landfills constituted $0.3 \%$ of all GPS locations in the Bay of Fundy.

\section{Analysis of prey selection using stable isotopes}

Potential prey items were homogenized, analyzed for mean $\delta^{13} \mathrm{C}$ and $\delta^{15} \mathrm{~N}$ and then grouped according to isotopic and biological similarity, resulting in five prey categories that served as the basis for subsequent MixSIAR analyses (Table 3). Isotopic separation was best along the $\delta^{15} \mathrm{~N}$ gradient (category averages ranged from $\delta^{15} \mathrm{~N}$ of $5.1 \%$ to $11.8 \%$ ) and overlapped more extensively along the $\delta^{13} \mathrm{C}$ gradient (category averages ranged from $\delta^{13} \mathrm{C}$ of $-21.5 \%$ to $-15.9 \%$; Table 3, Fig. 3). An increase in $\delta^{15} \mathrm{~N}$ between samples is typically interpreted to reflect an animal's increase in trophic position in the food web, whereas an increase in $\delta^{13} \mathrm{C}$ between samples is typically indicative of an animal that lives in a more marine (vs. in-shore or terrestrial) environment.

ANOVA of blood samples showed that colony was an important factor contributing to differences in mean stable-isotope values, with Brier Island gulls showing lower mean $\delta^{13} \mathrm{C}(-19.0 \pm 0.4 \%$ ) and $\delta^{15} \mathrm{~N}(11.9 \pm 1.1 \%)$ than Kent Island gulls $\left(\delta^{13} \mathrm{C}:-17.9\right.$ $\pm 0.8 \%, \delta^{15} \mathrm{~N}: 12.5 \pm 1.0 \%$ ) for samples collected within the same year, $2015\left(P_{\delta}{ }^{13} \mathrm{C}<0.001, P_{\delta}{ }^{15} \mathrm{~N}=0.024\right.$; Fig. $\left.3 \mathrm{~A}\right)$. Year also had 
a significant effect on $\delta^{13} \mathrm{C}(P<0.001)$ for the Brier Island colony, where two breeding seasons of data were available for analysis (2014: $-19.5 \pm 0.3 \%$, 2015: $-19.0 \pm 0.4 \%$ ). We did not detect a significant effect of year on $\delta^{15} \mathrm{~N}$ values derived from Brier Island $(P=0.365)$ blood samples (Fig. 3A).

Fig. 2. Proportion of GPS locations that fell into "known anthropogenic mink" or "known anthropogenic fisheries" prey source categories for Herring Gull (Larus argentatus) captured on nests in the Bay of Fundy, Canada. Gulls that were captured on Brier Island, Nova Scotia are shown in pink $(N=16$ individuals that made 2092 off-colony trips during the breeding seasons; Bird IDs 201-212 solar loggers, May-July 2014-2016; Bird IDs 213-217 battery loggers, May-June 2014) and individuals from Kent Island, New Brunswick are shown in blue ( $N=11$ individuals that made 2163 off-colony trips during the breeding seasons; Bird IDs 317-330 solar loggers, May-July 2015-2016). The GPS data set was filtered to include only offcolony locations ( $>500 \mathrm{~m}$ from an individual's nest) where speed was $<2 \mathrm{~km} / \mathrm{h}$ to target foraging and roosting destinations. Error bars show the standard deviation per individual over multiple time periods, i.e., breeding stages (incubation vs. chick-rearing), and/or years.

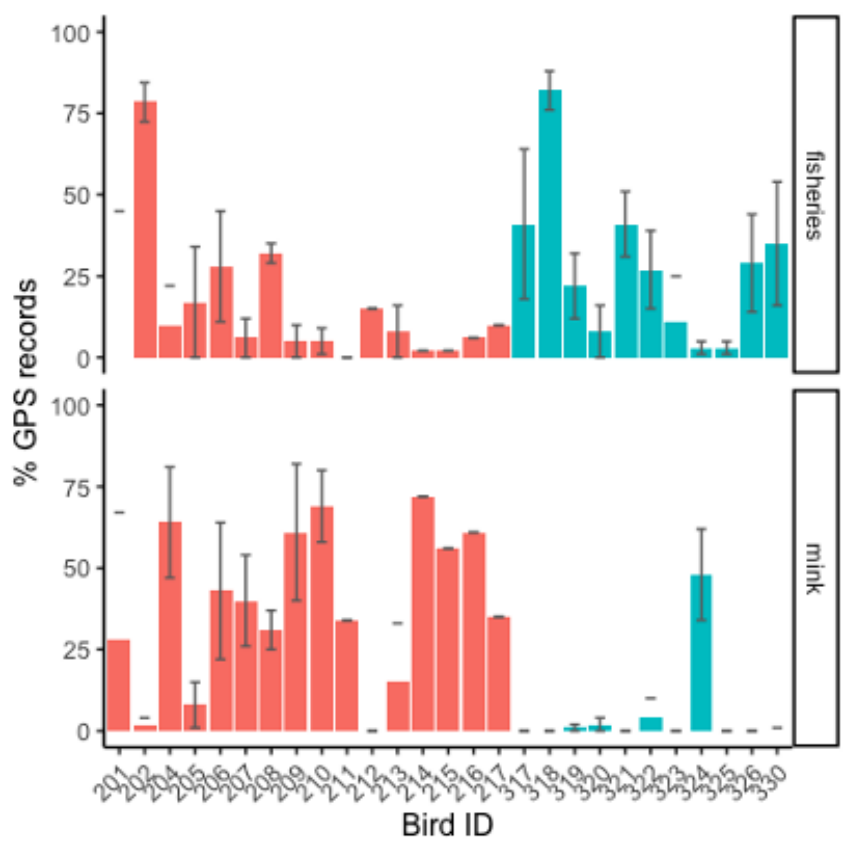

Conversely, ANOVA of feather samples suggested that colony contributed to variation in $\delta^{13} \mathrm{C}$ (Brier Island: $-17.4 \pm 0.5 \%$, Kent Island: $-16.7 \pm 0.7 \%, P=0.010)$ but not $\delta^{15} \mathrm{~N}(P=0.567)$ within the same year, 2015 (Fig. 3B). On Brier Island, where sampling took place in 2014 and 2015 , year affected neither $\delta^{13} \mathrm{C}(P=0.174)$ nor $\delta^{15} \mathrm{~N}(P=0.121$; Fig. 3B $)$.

Mixing model results show that gulls from Brier Island rely most heavily on the high trophic marine prey category (mean $[95 \% \mathrm{CI}]$ : blood: 29 [9-51]\% of diet; feathers: 29 [8-49]\% of diet), whereas gulls from Kent Island rely most heavily on the crabs prey category (blood: 56 [40-67]\% of diet; feathers: 49 [35-63]\% of diet; Table 4). Mink and industrial discards, the two solely anthropogenic categories, were moderately important in both colonies, constituting mean contribution estimates up to $21 \%$ and $19 \%$, respectively (Table 4 ). The low trophic marine prey category, i.e., prey that gulls catch wild, was also of moderate importance in both colonies, constituting a mean contribution estimate of up to $18 \%$ of gull diet at Brier Island and up to $12 \%$ of gull diet at Kent Island (Table 4). Isotope analysis cannot be used to determine what proportion of prey from the high trophic marine and crabs categories is anthropogenically sourced.

Fig. 3. The $\delta^{13} \mathrm{C}$ and $\delta^{15} \mathrm{~N}$ values (\%o) of whole blood (A) and feathers (B) sampled from nesting Herring Gull (Larus argentatus) at Brier Island, Nova Scotia and Kent Island, New Brunswick, Canada plotted among the mean isotope values of potential prey categories (see Table 3). Prey categories were adjusted by discrimination factors relative to bird tissue samples. Brier Island: $N$ blood $=56$, feathers $=59$; Kent Island: $N$ blood $=34$, feathers $=14$.
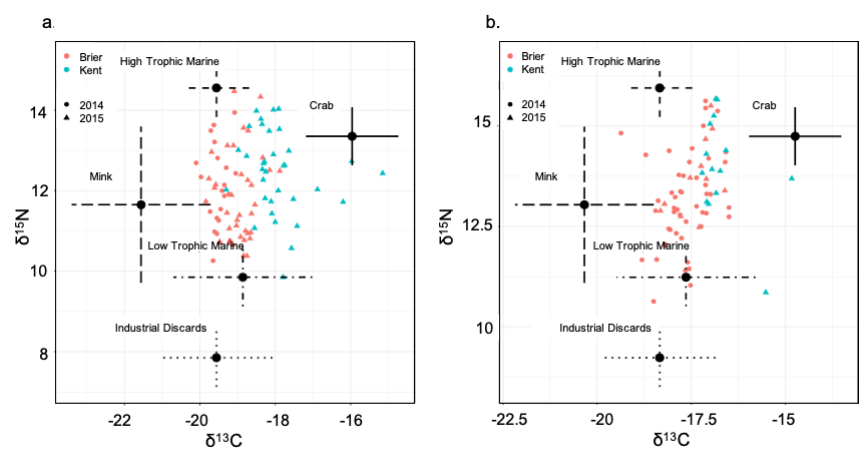

\section{Estimating anthropogenic resource use with combined methods}

For the Brier Island colony, resource use (prey source-prey type) scores ranged from 9 to 29 , with $50 \%$ of them ranging from 17 to 23 (Fig. 4A). Resources with the highest scores include known anthropogenic mink farms-mink feed/carcasses (score $=29$ ), unassigned coastal habitat-high trophic marine prey (28), and known anthropogenic fisheries-high trophic marine prey (score $=26$ ). Resources with the lowest scores include unassigned marine habitat-low trophic marine prey (9), unassigned marine habitatindustrial discards (score $=12$ ), and both logical unassigned terrestrial habitat pairings (scores $=13-14)$.

Resource use at the Kent Island colony ranged from 5 to 59, with $50 \%$ of resource use scores ranging from 7 to 19 (Fig. 4B). All logical unassigned coastal habitat-prey type pairings scored $\geq 35$, including the resource with the highest score, unassigned coastal habitat-crab (score $=59$ ). The second highest scoring resource was known anthropogenic fisheries-crab (score $=42$ ). Resources with the lowest scores included industrial discards from known anthropogenic landfills (score $=5$ ) and unassigned terrestrial $($ score $=5$ ) or marine habitats (score $=6)$, as well as marine prey from unassigned marine sources (score $=7$ ). 
Fig. 4. Estimation of the relative importance of various wild and anthropogenic food resources available to Herring Gull (Larus argentatus) captured on Brier Island, Nova Scotia (A) and Kent Island, New Brunswick (B), Canada, during the breeding seasons in May-July 2014-2016. Prey type: mean estimates (\%) of the proportion of the diet that comprises each of five prey-type categories are the results of a separate stable-isotope analysis (see Table 4). Source: mean estimates (\%) of GPS points that were assigned to each of six prey-source categories are the results of a separate GPS analysis (see Table 2). Each score in the table is the average between a prey-type category and a prey-source category; ecologically illogical prey source-prey type combinations are labeled. Scores can be used objectively to weigh the importance of specific wild (green) or anthropogenic (yellow) resources relative to other resources available to gulls. Higher resource use scores (darker cells) indicate that gulls consumed high levels of a prey type that is obtained from a habitat type where gulls spent a lot of time foraging, therefore giving confidence that a particular wild or anthropogenic resource is an important part of the gull diet.

a) Brier Island colony, NS, Canada
Prey type - What do gulls eat? Mean estimate (\%): stable-isotope (Table 4)

$\begin{array}{ccccc}\text { Mink } & \begin{array}{c}\text { Industrial } \\ \text { Discards }\end{array} & \text { Crab } & \begin{array}{c}\text { High Trophic } \\ \text { Marine }\end{array} & \begin{array}{c}\text { Low Trophic } \\ \text { Marine }\end{array} \\ \text { Mink } & \text { Fisheries waste, } & \text { Green/Jonah } & \text { Fish, gull } & \text { Bivalves, krill, } \\ \text { feed/carcass } & \text { compost } & \text { crab } & \text { egg/carcass } & \text { amphipods }\end{array}$

Fisheries Wharfs, canneries

Mink

Mink fur farms

Other

Landfills

Terrestrial

$>3 \mathrm{~km}$ inland

Coastal

$\pm 3 \mathrm{~km}$ shoreline

Marine

$>3 \mathrm{~km}$ offshore

19

19

29

13

\begin{tabular}{|c|c|c|c|c|}
\hline illogical & 21 & 21 & 26 & 18 \\
\hline 29 & illogical & illogical & illogical & illogical \\
\hline illogical & 10 & illogical & illogical & illogical \\
\hline 14 & 13 & illogical & illogical & illogical \\
\hline illogical & 23 & 23 & 28 & 20 \\
\hline illogical & 12 & illogical & 17 & 9 \\
\hline
\end{tabular}

23
37
0
6
28
5

b) Kent Island colony, NB, Canada

\begin{tabular}{|c|ccc|c|}
\multicolumn{5}{c}{ Prey type - What do gulls eat? } \\
Mink & $\begin{array}{c}\text { Mean estimate (\%): stable-isotope (Table 4) } \\
\text { Mink } \\
\text { Discards } \\
\text { feed/carcass } \\
\text { Fisheries waste, } \\
\text { compost }\end{array}$ & $\begin{array}{c}\text { Green/Jonah } \\
\text { crab }\end{array}$ & $\begin{array}{c}\text { Marine } \\
\text { Fish, gull } \\
\text { egg/carcass }\end{array}$ & $\begin{array}{c}\text { Mow Trophic } \\
\text { Mival ves, krill, } \\
\text { amphipods }\end{array}$ \\
\hline illogical & 18 & 56 & 10 & 10 \\
\hline 11 & illogical & illogical & illogical & illogical \\
\hline illogical & 5 & illogical & illogical & illogical \\
\hline 9 & 5 & illogical & illogical & illogical \\
\hline illogical & 35 & 59 & 36 & 36 \\
\hline illogical & 6 & illogical & 7 & 7 \\
\hline
\end{tabular}

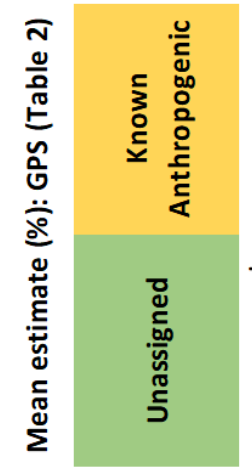

Fisheries

Wharfs, canneries

Mink

Mink fur farms

Othe

Terrestrial

Coastal

$\pm 3 \mathrm{~km}$ shoreline

Marine 
Table 3. Average $\delta^{13} \mathrm{C}$ and $\delta^{15} \mathrm{~N}(\%)$ of potential prey type categories included in the stable-isotope mixing model. All prey items were collected in Nova Scotia, Canada, including the Bay of Fundy, in April-September 2015. Prey items were homogenized and analyzed as a single sample; therefore, standard deviations for individual prey items are not shown.

\begin{tabular}{|c|c|c|c|c|c|c|c|}
\hline Prey type category & $\delta^{13} \mathrm{C}\left(\mathrm{SD}^{\dagger}\right)$ & $\delta^{15} \mathrm{~N}\left(\mathrm{SD}^{\dagger}\right)$ & Prey item & $N$ & $\delta^{13} \mathrm{C}$ & $\delta^{15} \mathrm{~N}$ & Anticipated source \\
\hline \multirow[t]{4}{*}{ High trophic marine } & $-19.5(0.5)$ & $11.8(0.6)$ & Atlantic mackerel (Scomber scombrus) & 2 & -19.2 & 11.8 & Either \\
\hline & & & Atlantic herring (Clupea harengus) & 3 & -19.7 & 12.2 & Either \\
\hline & & & Gull (Larus argentatus) egg & 2 & -19.0 & 12.3 & Wild \\
\hline & & & Gull (L. argentatus) chick & 3 & -20.2 & 11.0 & Wild \\
\hline \multirow[t]{2}{*}{$\mathrm{Crab}$} & $-15.9(1.0)$ & $10.6(0.6)$ & Green crab (Carcinus maenas) & 3 & -15.2 & 10.2 & Wild \\
\hline & & & Jonah crab (Cancer borealis) & 2 & -16.6 & 11.0 & Either \\
\hline \multirow[t]{4}{*}{ Low trophic marine } & $-18.8(1.7)$ & $7.1(0.6)$ & Amphipod (Order Amphipoda) & 15 & -17.0 & 7.7 & Wild \\
\hline & & & Soft-shell clam (Mya arenaria) & 5 & -17.8 & 7.3 & Wild \\
\hline & & & Blue mussel (Mytilus edulis) & 3 & -20.1 & 6.3 & Wild \\
\hline & & & Krill (Order Euphausiacea) & 15 & -20.3 & 7.1 & Wild \\
\hline \multirow[t]{2}{*}{ Mink } & $-21.5(1.7)$ & $8.9(1.9)$ & Mink feed (early spring) & 2 & -23.3 & 7.0 & Anthropogenic \\
\hline & & & Mink (Neovison vison) carcass & 2 & -20.3 & 10.2 & Anthropogenic \\
\hline \multirow[t]{3}{*}{ Industrial discards } & $-19.5(1.3)$ & $5.1(0.6)$ & Aquaculture salmon feed & 1 & -18.7 & 4.4 & Anthropogenic \\
\hline & & & Lobster factory discards & 2 & -21.0 & 5.6 & Anthropogenic \\
\hline & & & City compost & 1 & -18.8 & 5.3 & Anthropogenic \\
\hline
\end{tabular}

Standard deviation.

"Indicates whether a particular prey item is expected to have been obtained by gulls from the wild, from an anthropogenic location, or when the origin could be either wild or anthropogenic.

\section{DISCUSSION}

\section{Anthropogenic resource use}

Together, the GPS and stable-isotope results suggest that prey from anthropogenic sources are likely to be an important part of the diet of herring gulls that nest in the Bay of Fundy, Canada. Gulls from both colonies consumed high levels of crab and high trophic marine prey categories (e.g., Atlantic herring [Clupea harengus], Atlantic mackerel), which are available and accessed by gulls at both known anthropogenic locations (i.e., fisheries). They also consumed either unidentified anthropogenic or nonanthropogenic prey sources.

Our results also provide strong evidence that landfills and terrestrial destinations in general, excluding mink sites, do not provide significant food subsidies to gulls in the Bay of Fundy during the breeding season. In the GPS analysis, the terrestrial categories (known anthropogenic other and unassigned terrestrial) had the lowest or second lowest use scores among all six prey source categories on both islands. In the stable-isotope mixing model results, the industrial discards category, which featured human refuse (compost), received a moderate use score relative to the other four prey type categories for Brier Island gulls and the lowest relative use score for Kent Island gulls. Taken together, the anthropogenic resource use estimate showed that where gulls scored higher in the industrial discards prey type category, the prey source is much likelier to be from known anthropogenic fisheries or unassigned coastal habitats than from an inland location such as a landfill. Finally, we reiterate that we ultimately excluded terrestrial arthropod prey types from the stable-isotope mixing models because their $\delta^{13} \mathrm{C}$ and $\delta^{15} \mathrm{~N}$ values were extreme compared to all gull tissue samples.

On average, gulls from Brier Island travelled further from their nests than gulls from Kent Island to access locations where mink sites inadvertently supplied food in the form of fallen mink feed or improperly disposed mink carcasses. Approximately half of the gulls from Brier Island spent the majority of their off-colony time at sites where anthropogenic food is known to be available, particularly mink sources. Even though the mink prey category received the second highest use estimate by stable-isotope mixing models, it received the highest overall score in the anthropogenic resource use estimate (i.e., combined GPS and stable-isotope results). Gulls nesting on Kent Island relied less on anthropogenic food types overall, although approximately one-third of Kent Island birds' off-colony movements still fell into one of the anthropogenic source categories, predominantly known anthropogenic fisheries. The stable-isotope results were less definitive because all prey type categories had wide confidence intervals and no single category was estimated to be a majority of gulls' diet at either colony.

Blood and feather samples produced similar results in the stableisotope analysis, with the strongest pattern being clear colonylevel separation in $\delta^{13} \mathrm{C}$ rather than trophic level $\left(\delta^{15} \mathrm{~N}\right)$. Because the innermost primary feathers reflect the diet at the time of feather growth, these samples reflect the individuals' diets during incubation (approximately May) of the year prior to sample collection, whereas blood, which turns over on a monthly basis, reflects the individual's diet during the incubation period of sample collection (Hobson and Clark 1992a). Therefore, the observed consistency in blood and feather model outputs over both tissue types and years suggests consistency in colony-level diets across at least two years.

\section{Study limitations and future research}

We have noted differences in the estimates produced by GPS and stable-isotope analyses of gulls' reliance on anthropogenic food sources. From the GPS perspective, this difference could indicate that a large portion of gulls' off-colony stopovers are nonforaging destinations (i.e., roost sites) or are foraging destinations where prey is infrequently or unpredictably available. Alternatively, the estimates produced by stable-isotope mixing models may be influenced by the way we combined potential prey items into prey 
Table 4. Mean percentage (and 95\% confidence interval) contribution of each prey type category as estimated by Bayesian mixing models. Dietary estimates were derived from $\delta^{13} \mathrm{C}$ and $\delta^{15} \mathrm{~N}$ values from whole blood and primary feathers sampled from nesting Herring Gull (Larus argentatus) at Brier Island, Nova Scotia $(N$ blood $=56$, feathers $=59)$ and Kent Island, New Brunswick $(N$ blood $=34$, feathers $=14$ ), Canada. Average values are shown for Brier Island only where sampling took place over two years (see Table 1).

\begin{tabular}{|c|c|c|c|c|c|c|c|}
\hline \multirow[b]{2}{*}{ Colony } & \multirow[b]{2}{*}{ Year } & \multirow[b]{2}{*}{ Tissue } & \multicolumn{5}{|c|}{ Prey type category } \\
\hline & & & Mink & Industrial discards & Crab & High trophic marine & Low trophic marine \\
\hline$\overline{\text { Brier }}$ & 2014 & Blood & $18(4-34)$ & $18(4-31)$ & $12(3-23)$ & $41(23-58)$ & $11(0-26)$ \\
\hline \multirow[t]{5}{*}{ Island } & & Feather & $11(0-30)$ & $18(0-36)$ & $22(11-35)$ & $29(9-43)$ & $20(1-47)$ \\
\hline & 2015 & Blood & $20(4-37)$ & $17(3-30)$ & $27(15-39)$ & $24(6-42)$ & $12(0-31)$ \\
\hline & & Feather & $10(0-29)$ & $14(0-30)$ & $28(16-42)$ & $31(8-48)$ & $17(1-40)$ \\
\hline & & Average blood & $21(5-45)$ & $19(4-42)$ & $19(6-38)$ & $29(9-51)$ & $13(1-35)$ \\
\hline & & Average feather & $12(1-33)$ & $17(1-38)$ & $25(10-42)$ & $29(8-49)$ & $18(1-43)$ \\
\hline Kent & 2015 & Blood & $17(1-32)$ & $8(1-20)$ & $56(40-67)$ & $10(1-26)$ & $10(0-35)$ \\
\hline Island & & Feather & $8(0-27)$ & $9(0-23)$ & $49(35-63)$ & $22(3-39)$ & $12(0-34)$ \\
\hline
\end{tabular}

categories (Phillips et al. 2005) or by uncertainty about discrimination factors (Bond and Diamond 2011). Such limitations are especially troublesome when analyzing generalist predators such as the Herring Gull, for which the list of possible prey sources spans nearly the entire range of $\delta^{13} \mathrm{C}$ and $\delta^{15} \mathrm{~N}$ values that can be found in the study area. Additionally, in eastern Canada, ground Atlantic herring is often used as the primary ingredient in both mink feed and aquaculture salmon feed, so these two prey items, in combination with wild-caught herring, are indistinguishable to isotope mixing models. Moreover, Atlantic herring and other high trophic-level fish are used as bait in local lobster fisheries, which are active in May and June, and herring gulls frequently scavenge for discarded bait around vessels at sea.

We circumvented these challenges of stable-isotope analysis by combining the results with results from the GPS analysis. Because the GPS analysis suggests that gulls spend much of their time at coastal or inland sites and little time offshore, we can infer that gulls in the Bay of Fundy are more likely to obtain Atlantic herring, and thus high trophic marine prey, through anthropogenic sources such as fish processing plants or mink (Brier Island) and salmon (Kent Island) feed. Moreover, the availability of herring as lobster bait in the marine environment likely declines after the lobster season's annual closure (May 31, Brier Island region; June 29, Kent Island region), making terrestrial sources of herring (i.e., mink feed, aquaculture salmon feed) the most likely sources during the gulls' chick-rearing stage (early June to mid-August).

It is possible that our GPS analysis is biased against at-sea foraging. We filtered GPS records to include only near-stationary speeds $(<2 \mathrm{~km} / \mathrm{h})$ after the preliminary observation that gull attendance in the marine environment truly was low relative to coastal and inland areas. However, possible specialists in marine foraging deserve more attention in future studies. Another possible biasing issue relates to our decision to analyze GPS data from Brier Island in 2014, including data from five gulls with an alternate logger type (battery instead of solar), even though Kent Island data collection did not begin until 2015. Including the additional year (2014) and logger type on Brier Island maximized what could be learned about interannual and intracolony variation in prey sources but may have biased the colony-level averages that were highlighted in our combined GPS-isotope analysis. We believe this bias to be insignificant because categorical averages and variation were consistent between years in both the GPS and stable-isotope analyses, even in the incubation stage of 2014, when the alternate logger type contributed data. Nevertheless, further study of individual variation should be investigated.

\section{Evolutionary implications}

Though the Brier Island and Kent Island colonies are located 36 $\mathrm{km}$ apart (well within the typical foraging range of these species), we found colony-level differences in both foraging areas and prey types obtained in each category. These results are consistent with results from gull tagging studies in coastal California (Shaffer et al. 2017) and Germany (Corman et al. 2016, Enners et al. 2018), which identified diet and foraging habitat differences between gulls from different colonies within the same region. Optimal foraging theory posits that this apparent niche partitioning is an adaptive response to intraspecific competition (Kotler and Brown 2007, Corman et al. 2016).

It is rarely known whether individual variation in gull foraging behaviors is the result of behavioral plasticity, local adaptation, or both (Maynard and Ronconi 2018). A single experimental translocation study of the Lesser Black-backed Gull in northern Europe and western Asia suggests that plasticity is the primary driver of observed geographic variation in diet (van Toor et al. 2017); however, more work is needed to understand the implications of individual variation for population dynamics and species conservation. If individuals are truly generalist opportunists, they may be able to compensate for the loss of one food type by switching to another (Kotler and Brown 2007). However, if gulls are locally adapted (i.e., specialized) or are limited by the types of prey available to them, rapid changes in a single prey type may have dramatic consequences to gull survival and reproduction. For example, Kent Island gulls have shown long-term variation in egg size, which tracks the availability of fisheries-related food sources over a 28-yr period (Bennett et al. 2017). In the near term, food shortages may cause individuals to skip breeding seasons until prey return to adequate abundance or availability so as to elevate adult condition and warrant investment in breeding efforts. Long term, individuals may emigrate to new breeding areas in search of more abundant or available prey. Gull responses on both time scales may have 
contributed to the decline in nest numbers that has been witnessed on Kent Island since the mid-20th century (Ronconi and Wong 2003, Bennett et al. 2017).

Variation in diet at the individual and colony levels may ultimately explain differences in annual productivity and colony return rates if the energetic gains from these prey types also vary, either because different prey types vary in quality (Pierotti and Annett 1991, Weiser and Powell 2010) or because different prey types demand alternative foraging strategies that may trade off with nest attendance (Hunt 1972, Shaffer et al. 2017) or other behavioral factors (O'Hanlon et al. 2017). Future research should therefore focus directly on the relationships between prey choice and productivity at the nest level, which may reveal further understanding of population dynamics within colonies.

\section{Conservation implications}

The standing hypothesis explaining the widespread, long-term declines in Larus species as observed in eastern North America is that gulls have been unable to adapt to the decrease in total prey availability due to improvements in waste management and the collapse of multiple major marine fisheries (MacKinnon and Kennedy 2014, Anderson et al. 2016, Wilhelm et al. 2016). The literature has focused on a decreased volume of available prey, but changes in the overall quality of the diet, especially in relation to artificial prey types, may play an equally important role. Regardless, a critical information gap has been in understanding whether pivotal changes to diet are related to changing anthropogenic sources, natural sources, or both. If the total prey decrease is caused primarily by the elimination of human industrial practices that inadvertently supply food, then we might predict that earlier peak populations were "artificially" inflated and are predictably returning to sustainable, presubsidy breeding numbers. If, however, the reduction in total prey available to gulls comes partly or entirely from reduced natural food sources, then wildlife managers must be prepared to mitigate unsustainable declines in gull numbers as anthropogenic sources of prey are eliminated.

Our results indicate that crab and high trophic marine prey from both wild and anthropogenic sources are key components of the diet of gulls at the two largest colonies in the Bay of Fundy. Wildlife managers should therefore exercise caution in assuming that future elimination of anthropogenic food subsidies will result in a gull population decline to sustainable, preindustrial colony sizes. Elimination of mink farms as a prey source may very well lead to a local decline in gull numbers (and is perhaps already being observed), but it is unclear whether gulls, especially those from Brier Island, have access to wild food types that they are not currently using. The future of gulls within foraging range of modern mink farm activity centers therefore remains to be seen.

\section{Conclusion}

GPS tracking and stable-isotope analysis are two complementary approaches to understanding gull foraging ecology, and each has strengths and biases. Along with site-level field observations pertaining to the natural history of the species, these methods allowed us to better explore sources of variation in gull diets, especially in relation to these birds' relative reliance on anthropogenic sources of food. Understanding how human activities influence gull behavior permits improvements in the design and implementation of wildlife management strategies that mitigate undesired anticipated effects on gulls and gull populations and on the ecosystems to which they belong. Ultimately, this information can be used to inform the adaptive management of gulls, which is especially vital in the face of global climate change and other causes of intensive landscape alteration.

Responses to this article can be read online at: https://www.ace-eco.org/issues/responses.php/1739

\section{Acknowledgments:}

We thank the following individuals and organizations for their contributions to this manuscript: two anonymous reviewers for thoughtful, constructive comments; Environment and Climate Change Canada, New Brunswick Wildlife Council, Nova Scotia Department of Natural Resources, and the University of New Brunswick for funding; $S$. Wilhelm and $G$. Robertson for guidance and equipment; Z. Crysler, L. Maynard, and C. Schollaert for field assistance; the staff at the Stable Isotopes in Nature Laboratory, Fredericton, New Brunswick for providing training and workspace; D. Gannon and the Bowdoin Scientific Station, W. DeVries, and N. Hill for local logistical support; Sea Crest Fisheries Ltd., M. Moses, and one anonymous source for donating mink samples; and J.G.T. Anderson, S. LaZerte, and members of the Atlantic Lab for Avian Research for advice and encouragement. Field methods and sample collection were approved under UNB Animal Care protocol 14027.

\section{LITERATURE CITED}

Ackerman, J. T., S. H. Peterson, D. C. Tsao, and J. Y. Takekawa. 2018. California Gull (Larus californicus) space use and timing of movements in relation to landfills and breeding colonies. Waterbirds 41(4):384-400. https://doi.org/10.1675/063.041.0402

Anderson, J. G. T., K. R. Shlepr, A. L. Bond, and R. A. Ronconi. 2016. Introduction: a historical perspective on trends in some gulls in eastern North America, with reference to other regions. Waterbirds 39(sp1):1-9. https://doi.org/10.1675/063.039.sp106

Annett, C. A., and R. Pierotti. 1999. Long-term reproductive output in western gulls: consequences of alternate tactics in diet choice. Ecology 80(1):288-297. https://doi.org/10.1890/0012-9658 (1999)080[0288:LTROIW]2.0.CO;2

Bearhop, S., S. Waldron, S. C. Votier, and R. W. Furness. 2002. Factors that influence assimilation rates and fractionation of nitrogen and carbon stable isotopes in avian blood and feathers. Physiological and Biochemical Zoology 75(5):451-458. https://doi. org/10.1086/342800

Becker, B. H., S. H. Newman, S. Inglis, and S. R. Beissinger. 2007. Diet-feather stable isotope $\left(\delta^{15} \mathrm{~N}\right.$ and $\left.\delta^{13} \mathrm{C}\right)$ fractionation in common murres and other seabirds. Condor 109(2):451-456. https://doi.org/10.1650/0010-5422(2007)109[451:DSINAC]2.0.CO;2

Bennett, J. L., E. G. Jamieson, R. A. Ronconi, and S. N. P. Wong. 2017. Variability in egg size and population declines of Herring 
Gulls in relation to fisheries and climate conditions. Avian Conservation and Ecology 12(2):16. https://doi.org/10.5751/ ACE-01118-120216

Blight, L. K., D. F. Bertram, and E. Kroc. 2019. Evaluating UAVbased techniques to census an urban-nesting gull population on Canada's Pacific coast. Journal of Unmanned Vehicle Systems 7 (4):312-324. https://doi.org/10.1139/juvs-2019-0005

Blight, L. K., K. A. Hobson, T. K. Kyser, and P. Arcese. 2015. Changing gull diet in a changing world: a 150-year stable isotope $\left(\delta^{13} \mathrm{C}, \delta^{15} \mathrm{~N}\right)$ record from feathers collected in the Pacific Northwest of North America. Global Change Biology 21 (4):1497-1507. https://doi.org/10.1111/gcb.12796

Blokpoel, H., and G. D. Tessier. 1986. The Ring-billed Gull in Ontario: a review of a new problem species. Occasional Paper 57. Canadian Wildlife Service, Ottawa, Canada.

Bond, A. L. 2016. Diet changes in breeding herring gulls (Larus argentatus) in Witless Bay, Newfoundland and Labrador, Canada, over 40 years. Waterbirds 39(sp1):152-158. https://doi. org/10.1675/063.039.sp115

Bond, A. L., and A. W. Diamond. 2011. Recent Bayesian stableisotope mixing models are highly sensitive to variation in discrimination factors. Ecological Applications 21(4):1017-1023. https://doi.org/10.1890/09-2409.1

Bond, A. L., S. I. Wilhelm, G. J. Robertson, and S. Avery-Gomm. 2016. Differential declines among nesting habitats of breeding herring gulls (Larus argentatus) and great black-backed gulls (Larus marinus) in Witless Bay, Newfoundland and Labrador, Canada. Waterbirds 39(sp1):143-151. https://doi.org/10.1675/063.039. sp105

Cannell, P. F., and G. D. Maddox. 1983. Population change in three species of seabirds at Kent Island, New Brunswick. Journal of Field Ornithology 54(1):29-35. [online] URL: https://www.jstor. org/stable/4512784

Cherel, Y., K. A. Hobson, and S. Hassani. 2005. Isotopic discrimination between food and blood and feathers of captive penguins: implications for dietary studies in the wild. Physiological and Biochemical Zoology 78(1):106-115. https://doi. org/10.1086/425202

Clark, D. E., K. K. G. Koenen, K. G. MacKenzie, J. W. Pereira, and S. DeStefano. 2013. Stainless-steel wires exclude gulls from a wastewater treatment plant. Journal of the American Water Works Association 105(10):E609-E618. [online] URL: https:// www.jstor.org/stable/jamewatworass.105.10.e609

Cleary, E. C., R. A. Dolbeer, and S. E. Wright. 2006. Wildlife strikes to civil aircraft in the United States, 1990-2005. Federal Aviation Administration, Washington, D.C., USA. [online] URL: https://digitalcommons.unl.edu/cgi/viewcontent.cgi?referer= $\&$ httpsredir $=1 \&$ article $=1006 \&$ context $=$ birdstrikeother

Corman, A.-M., B. Mendel, C. C. Voigt, and S. Garthe. 2016. Varying foraging patterns in response to competition? A multicolony approach in a generalist seabird. Ecology and Evolution 6(4):974-986. https://doi.org/10.1002/ece3.1884

Coulson, J. C. 2015. Re-evaluation of the role of landfills and culling in the historic changes in the Herring Gull (Larus argentatus) population in Great Britain. Waterbirds 38 (4):339-354. https://doi.org/10.1675/063.038.0411

Cury, P. M., I. L. Boyd, S. Bonhommeau, T. Anker-Nilssen, R. J. M. Crawford, R. W. Furness, J. A. Mills, E. J. Murphy, H. Österblom, M. Paleczny, J. F. Piatt, J.-P. Roux, L. Shannon, and W. J. Sydeman. 2011. Global seabird response to forage fish depletion-one-third for the birds. Science 334:1703-1706. https://doi.org/10.1126/science.1212928

Diamond, A. W., and C. M. Devlin. 2003. Seabirds as indicators of changes in marine ecosystems: ecological monitoring on Machias Seal Island. Environmental Monitoring and Assessment 88:153-181. https://doi.org/10.1023/A:1025560805788

Donehower, C. E., and D. M. Bird. 2008. Gull predation and breeding success of common eiders on Stratton Island, Maine. Waterbirds 31(3):454-462. https://doi.org/10.1675/1524-4695-31.3.454

Drury, W. H., and J. A. Kadlec. 1974. The current status of the Herring Gull population in the northeastern United States. BirdBanding 45(4):297-306. https://doi.org/10.2307/4512069

Drury, W. H., and I. C. T. Nisbet. 1972. The importance of movements in the biology of herring gulls in New England. Pages 173-209 in R. L. Smith, J. R. Palmer, and T. S. Baskett, editors. Population ecology of migratory birds. Papers from a symposium held at the Migratory Bird Populations Station, Laurel, Maryland, 9-10 October 1969. Wildlife Research Report 2. U.S. Fish and Wildlife Service, Washington, D.C., USA.

Dwyer, C. P., J. L. Belant, and R. A. Dolbeer. 1996. Distribution and abundance of roof-nesting gulls in the Great Lakes region of the United States. Ohio Journal of Science 96(1):9-12. [online] URL: http://hdl.handle.net/1811/23691

Enners, L., P. Schwemmer, A.-M. Corman, C. C. Voigt, and S. Garthe. 2018. Intercolony variations in movement patterns and foraging behaviors among herring gulls (Larus argentatus) breeding in the eastern Wadden Sea. Ecology and Evolution 8 (15):7529-7542. https://doi.org/10.1002/ece3.4167

Farmer, R. G., and M. L. Leonard. 2011. Long-term feeding ecology of great black-backed gulls (Larus marinus) in the northwest Atlantic: 110 years of feather isotope data. Canadian Journal of Zoology 89(2):123-133. https://doi.org/10.1139/ z10-102

Foster, S., R. L. Swann, and R. W. Furness. 2017. Can changes in fishery landings explain long-term population trends in gulls? Bird Study 64(1):90-97. https://doi.org/10.1080/00063657.2016.1274287

Frechette, D., A.-M. K. Osterback, S. A. Hayes, J. W. Moore, S. A. Shaffer, M. Pavelka, C. Winchell, and J. T. Harvey. 2015. Assessing the relationship between gulls Larus spp. and Pacific salmon in central California using radiotelemetry. North American Journal of Fisheries Management 35(4):775-788. https:// doi.org/10.1080/02755947.2015.1032450

Frederick, P., D. E. Gawlik, J. C. Ogden, M. I. Cook, and M. Lusk. 2009. The White Ibis and Wood Stork as indicators for restoration of the everglades ecosystem. Ecological Indicators 9 (6):S83-S95. https://doi.org/10.1016/j.ecolind.2008.10.012

Gaston, A. J., D. F. Bertram, A. W. Boyne, J. W. Chardine, G. Davoren, A. W. Diamond, A. Hedd, W. A. Montevecchi, J. M. 
Hipfner, M. J. F. Lemon, M. L. Mallory, J.-F. Rail, and G. J. Robertson. 2009. Changes in Canadian seabird populations and ecology since 1970 in relation to changes in oceanography and food webs. Environmental Reviews 17:267-286. https://doi. org/10.1139/A09-013

Hébert, P. N. 1989. Decline of the Kent Island, New Brunswick, Herring Gull, Larus argentatus, colony. Canadian Field-Naturalist 103:394-396. [online] URL: https://www.biodiversitylibrary.org/ page/34348226

Hobson, K. A. 1987. Use of stable-carbon isotope analysis to estimate marine and terrestrial protein content in gull diets. Canadian Journal of Zoology 65(5):1210-1213. https://doi. org/10.1139/z87-187

Hobson, K. A., L. K. Blight, and P. Arcese. 2015. Human-induced long-term shifts in gull diet from marine to terrestrial sources in North America's coastal Pacific: more evidence from more isotopes $\left(\delta^{2} \mathrm{H}, \delta^{34} \mathrm{~S}\right)$. Environmental Science and Technology 49 (18):10834-10840. https://doi.org/10.1021/acs.est.5b02053

Hobson, K. A., and R. G. Clark. 1992a. Assessing avian diets using stable isotopes I: turnover of ${ }^{13} \mathrm{C}$ in tissues. Condor 94 (1):181-188. https://doi.org/10.2307/1368807

Hobson, K. A., and R. G. Clark. 1992b. Assessing avian diets using stable isotopes II: factors influencing diet-tissue fractionation. Condor 94(1):189-197. https://doi.org/10.2307/1368808

Hunt, G. L. Jr. 1972. Influence of food distribution and human disturbance on the reproductive success of herring gulls. Ecology 53(6):1051-1061. https://doi.org/10.2307/1935417

Jardine, T. D., and R. A. Cunjak. 2005. Analytical error in stable isotope ecology. Oecologia 144:528-533. https://doi.org/10.1007/ s00442-005-0013-8

Juvaste, R., E. Arriero, A. Gagliardo, R. Holland, M. J. Huttunen, I. Mueller, K. Thorup, M. Wikelski, J. Hannila, M.-L. Penttinen, and R. Wistbacka. 2017. Satellite tracking of red-listed nominate lesser black-backed gulls (Larus f. fuscus): habitat specialisation in foraging movements raises novel conservation needs. Global Ecology and Conservation 10:220-230. https://doi.org/10.1016/j. gecco.2017.03.009

Kadlec, J. A., and W. H. Drury. 1968. Structure of the New England Herring Gull population. Ecology 49(4):644-676. https:// doi.org/10.2307/1935530

Kavelaars, M. M., E. Stienen, H. Matheve, R.-J. Buijs, L. Lens, and W. Müller. 2018. GPS tracking during parental care does not affect early offspring development in lesser black-backed gulls. Marine Biology 165:87. https://doi.org/10.1007/s00227-018-3347-6

Kotler, B. P., and J. S. Brown. 2007. Community ecology. Pages 398-434 in D. W. Stephens, J. S. Brown, and R. C. Ydenberg, editors. Foraging: behavior and ecology. University of Chicago Press, Chicago, Illinois, USA.

Kroc, E. 2018. Reproductive ecology of urban-nesting glaucouswinged gulls Larus glaucescens in Vancouver, BC, Canada. Marine Ornithology 46:155-164. [online] URL: https://www. marineornithology.org/content/get.cgi?rn=1270
LaRue, D. 2016. Natural regeneration of the globally rare Geum peckii (Rosaceae) on Brier Island, Nova Scotia. Rhodora 118:310-314. https://doi.org/10.3119/15-39

MacKinnon, C. M., and A. C. Kennedy. 2014. Decline in breeding of the Great Black-backed Gull, Larus marinus, and the Herring Gull, L. argentatus, on Boot Island, Nova Scotia, 1986 to 2010. Canadian Field-Naturalist 126(2):165-172. https://doi.org/10.22621/ cfn.v128i2.1581

Mallory, M. L., and C. D. Gilbert. 2008. Leg-loop harness design for attaching external transmitters to seabirds. Marine Ornithology 36(2):183-188. [online] URL: https://www. marineornithology.org/content/get.cgi?rn=788

Maynard, L. D., and R. A. Ronconi. 2018. Foraging behaviour of great black-backed gulls Larus marinus near an urban centre in Atlantic Canada: evidence of individual specialization from GPS tracking. Marine Ornithology 46(1):27-32. [online] URL: https://www.marineornithology.org/content/get.cgi? $r n=1245$

Mittelhauser, G. H., R. B. Allen, J. Chalfant, R. P. Schauffler, and L. J. Welch. 2016. Trends in the nesting populations of herring gulls (Larus argentatus) and great black-backed gulls (Larus marinus) in Maine, USA, 1977-2013. Waterbirds 39(sp1):57-67. https://doi.org/10.1675/063.039.sp112

Nager, R. G., and N. J. O'Hanlon. 2016. Changing numbers of three gull species in the British Isles. Waterbirds 39(sp1):15-28. https://doi.org/10.1675/063.039.sp108

Nisbet, I. C. T., R. R. Veit, S. A. Auer, and T. P. White. 2013. Marine birds of the eastern United States and the Bay of Fundy: distribution, numbers, trends, threats, and management. Nutall Ornithological Club Publication 29. Nutall Ornithological Club, Cambridge, Massachusetts, USA.

Nisbet, I. C. T., D. V. Weseloh, C. E. Hebert, M. L. Mallory, A. F. Poole, J. C. Ellis, P. Pyle, and M. A. Patten. 2017. Herring Gull (Larus argentatus), version 3.0. In P. G. Rodewald, editor. The Birds of North America. Cornell Lab of Ornithology, Ithaca, New York, USA. https://doi.org/10.2173/bna.hergul.03

O'Hanlon, N. J., R. A. R. McGill, and R. G. Nager. 2017. Increased use of intertidal resources benefits breeding success in a generalist gull species. Marine Ecology Progress Series 574:193-210. https://doi.org/10.3354/meps12189

Osterback, A.-M. K., D. M. Frechette, S. A. Hayes, S. A. Shaffer, and J. W. Moore. 2015. Long-term shifts in anthropogenic subsidies to gulls and implications for an imperiled fish. Biological Conservation 191:606-613. https://doi.org/10.1016/j.biocon.2015.07.038

Parker, M. 2012. Offshore ecosystems and habitat: state of the Gulf of Maine report. Gulf of Maine Association, Ogunquit, Maine, USA. [online] URL: http://www.gulfofmaine.org/2/wp-content/ uploads/2014/03/offshore-ecosystems-and-habitats.pdf

Perlut, N. G., D. N. Bonter, J. C. Ellis, and M. S. Friar. 2016. Rooftop nesting in a declining population Of herring gulls (Larus argentatus) in Portland, Maine, USA. Waterbirds 39(sp1):68-73. https://doi.org/10.1675/063.039.sp113

Pershing, A. J., M. A. Alexander, C. M. Hernandez, L. A. Kerr, A. Le Bris, K. E. Mills, J. A. Nye, N. R. Record, H. A. Scannell, 
J. D. Scott, G. D. Sherwood, and A. C. Thomas. 2015. Slow adaptation in the face of rapid warming leads to collapse of the Gulf of Maine cod fishery. Science 350:809-812. https://doi. org/10.1126/science.aac9819

Phillips, D. L., S. D. Newsome, and J. W. Gregg. 2005. Combining sources in stable isotope mixing models: alternative methods. Oecologia 144:520-527. https://doi.org/10.1007/s00442-004-1816-8

Pierotti, R., and C. A. Annett. 1991. Diet choice in the Herring Gull: constraints imposed by reproductive and ecological factors. Ecology 72(1):319-328. https://doi.org/10.2307/1938925

Province of New Brunswick. 2013. New Brunswick wild blueberry sector strategy 2013-2018. Province of New Brunswick, Fredericton, Canada. [online] URL: https://www2.gnb.ca/ content/dam/gnb/Departments/10/pdf/Agriculture/WildBlueberriesBleuetsSauvages/WildBlueberryStrategy.pdf

R Core Development Team. 2019. R: a language and environment for statistical computing. R Foundation for Statistical Computing, Vienna, Austria. [online] URL: https://www.r-project.org/

Ramírez, F., C. Gutiérrez-Expósito, I. Afán, J. Giménez, R. de Stephanis, and M. G. Forero. 2015. Human influence on gull nonbreeding distribution: potential consequences of changes in fishing practices. Marine Ecology Progress Series 527:221-232. https://doi.org/10.3354/meps11282

Raven, S. J., and J. C. Coulson. 1997. The distribution and abundance of Larus gulls nesting on buildings in Britain and Ireland. Bird Study 44(1):13-34. https://doi.org/10.1080/00063659709461035

Robertson, G. J., S. Roul, K. A. Allard, C. Pekarik, R. A. Lavoie, J. C. Ellis, N. G. Perlut, A. W. Diamond, N. Benjamin, R. A. Ronconi, S. G. Gilliland, and B. G. Veitch. 2016. Morphological variation among herring gulls (Larus argentatus) and great blackbacked gulls (Larus marinus) in eastern North America. Waterbirds 39(sp1):253-268. https://doi.org/10.1675/063.039. sp123

Ronconi, R. A., R. J. Steenweg, P. D. Taylor, and M. L. Mallory. 2014. Gull diets reveal dietary partitioning, influences of isotopic signatures on body condition, and ecosystem changes at a remote colony. Marine Ecology Progress Series 514:247-261. https://doi. org/10.3354/meps 10980

Ronconi, R. A., and S. N. P. Wong. 2003. Estimates of changes in seabird numbers in the Grand Manan Archipelago, New Brunswick, Canada. Waterbirds 26(4):462-472. https://doi. org/10.1675/1524-4695(2003)026[0462:EOCISN]2.0.CO;2

Rosenberg, K. V., A. M. Dokter, P. J. Blancher, J. R. Sauer, A. C. Smith, P. A. Smith, J. C. Stanton, A. Panjabi, L. Helft, M. Parr, and P. P. Marra. 2019. Decline of the North American avifauna. Science 366(6461):120-124. https://doi.org/10.1126/science.aaw1313

Scopel, L. C., and A. W. Diamond. 2017. The case for lethal control of gulls on seabird colonies. Journal of Wildlife Management 81(4):572-580. https://doi.org/10.1002/jwmg.21233

Scopel, L. C., A. W. Diamond, S. W. Kress, A. R. Hards, and P. Shannon. 2018. Seabird diets as bioindicators of Atlantic herring recruitment and stock size: a new tool for ecosystem-based fisheries management. Canadian Journal of Fisheries and Aquatic Sciences 75(8):1215-1229. https://doi.org/10.1139/cjfas-2017-0140

Seif, S., J. F. Provencher, S. Avery-Gomm, P.-Y. Daoust, M. L. Mallory, and P. A. Smith. 2018. Plastic and non-plastic debris ingestion in three gull species feeding in an urban landfill environment. Archives of Environmental Contamination and Toxicology 74:349-360. https://doi.org/10.1007/s00244-017-0492-8

Shaffer, S. A., S. Cockerham, P. Warzybok, R. W. Bradley, J. Jahncke, C. A. Clatterbuck, M. Lucia, J. A. Jelincic, A. L. Cassell, E. C. Kelsey, and J. Adams. 2017. Population-level plasticity in foraging behavior of western gulls (Larus occidentalis). Movement Ecology 5:27. https://doi.org/10.1186/s40462-017-0118-9

Shamoun-Baranes, J., W. Bouten, C. J. Camphuysen, and E. Baaij. 2011. Riding the tide: intriguing observations of gulls resting at sea during breeding. Ibis 153(2):411-415. https://doi.org/10.1111/ j.1474-919X.2010.01096.X

Shlepr, K. R. 2017. The geography of diet: diversity in diet and foraging behavior in herring gulls (Larus argentatus) across Atlantic Canada. Thesis. University of New Brunswick, Fredericton, Canada. [online] URL: https://unbscholar.lib.unb. ca/islandora/object/unbscholar\%3A8358

Spelt, A., C. Williamson, J. Shamoun-Baranes, E. Shepard, P. Rock, and S. Windsor. 2019. Habitat use of urban-nesting lesser black-backed gulls during the breeding season. Scientific Reports 9:10527. https://doi.org/10.1038/s41598-019-46890-6

Steenweg, R. J., R. A. Ronconi, and M. L. Leonard. 2011. Seasonal and age-dependent dietary partitioning between the great black-backed and herring gulls. Condor 113(4):795-805. https://doi.org/10.1525/cond.2011.110004

Stock, B. C., A. L. Jackson, E. J. Ward, A. C. Parnell, D. L. Phillips, and B. X. Semmens. 2018. Analyzing mixing systems using a new generation of Bayesian tracer mixing models. PeerJ 6:e5096 https://doi.org/10.7717/peerj.5096

Thaxter, C. B., B. Lascelles, K. Sugar, A. S. C. P. Cook, S. Roos, M. Bolton, R. H. W. Langston, and N. H. K. Burton. 2012. Seabird foraging ranges as a preliminary tool for identifying candidate Marine Protected Areas. Biological Conservation 156:53-61. https://doi.org/10.1016/j.biocon.2011.12.009

Thaxter, C. B., V. H. Ross-Smith, J. A. Clark, N. A. Clark, G. J. Conway, E. A. Masden, H. M. Wade, E. H. K. Leat, S. C. Gear, M. Marsh, C. Booth, R. W. Furness, S. C. Votier, and N. H. K. Burton. 2016. Contrasting effects of GPS device and harness attachment on adult survival of lesser black-backed gulls Larus fuscus and great skuas Stercorarius skua. Ibis 158(2):279-290. https://doi.org/10.1111/ibi.12340

Toms, B. 2015. Habitat management and implications for Herring Gull monitoring at Brier Island, NS. In Eastern mountain avens: implementation of high priority recovery actions. Unpublished report for the Canadian Wildlife Service. Mersey Tobeatic Research Institute, Kempt, Canada.

van Toor, M. L., E. Arriero, R. A. Holland, M. J. Huttunen, R. Juvaste, I. Müller, K. Thorup, M. Wikelski, and K. Safi. 2017. Flexibility of habitat use in novel environments: insights from a 
translocation experiment with lesser black-backed gulls. Royal Society Open Science 4(1):160164. https://doi.org/10.1098/ rsos. 160164

Velarde, E., D. W. Anderson, and E. Ezcurra. 2019. Seabird clues to ecosystem health. Science 365:116-117. https://doi. org/10.1126/science.aaw9999

Weimerskirch, H. 2007. Are seabirds foraging for unpredictable resources? Deep Sea Research Part II: Topical Studies in Oceanography 54(3-4):211-223. https://doi.org/10.1016/j.dsr2.2006.11.013

Weiser, E. L., and A. N. Powell. 2010. Does garbage in the diet improve reproductive output of glaucous gulls? Condor 112 (3):530-538. https://doi.org/10.1525/cond.2010.100020

Weseloh, D. V., K. D. Hughes, P. J. Ewins, D. Best, T. Kubiak, and M. C. Shieldcastle. 2002. Herring gulls and great blackbacked gulls as indicators of contaminants in bald eagles in Lake Ontario, Canada. Environmental Toxicology and Chemistry 21 (5):1015-1025. https://doi.org/10.1897/1551-5028(2002)021<1015: HGAGBB $>2.0 . \mathrm{CO} ; 2$

Wilhelm, S. I., J.-F. Rail, P. M. Regular, C. Gjerdrum, and G. J. Robertson. 2016. Large-scale changes in abundance of breeding herring gulls (Larus argentatus) and great black-backed gulls (Larus marinus) relative to reduced fishing activities in southeastern Canada. Waterbirds 39(sp1):136-142. https://doi. org/10.1675/063.039.sp104

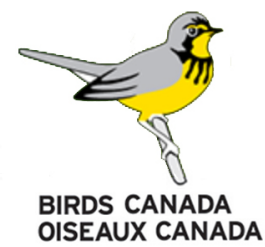


Supplementary Table 1. Total bird-days and affiliated metrics for each Bird ID used in this study.

\begin{tabular}{|l|l|l|l|l|l|l|l|}
\hline Colony & Tag type & Start date & End date & Bird ID & $\begin{array}{l}\text { No. } \\
\text { incubation } \\
\text { periods }\end{array}$ & $\begin{array}{l}\text { No. chick- } \\
\text { rearing } \\
\text { periods }\end{array}$ & $\begin{array}{l}\text { Total bird- } \\
\text { days }\end{array}$ \\
\hline Brier & solar & $2014-05-18$ & $2015-05-03$ & 201 & 2 & 1 & 66 \\
\hline Brier & solar & $2014-05-16$ & $2016-07-21$ & 202 & 3 & 3 & 201 \\
\hline Brier & solar & $2014-05-16$ & $2016-07-21$ & 204 & 3 & 3 & 193 \\
\hline Brier & solar & $2014-05-16$ & $2014-07-22$ & 205 & 1 & 1 & 66 \\
\hline Brier & solar & $2014-05-16$ & $2016-07-31$ & 206 & 3 & 3 & 196 \\
\hline Brier & solar & $2014-05-17$ & $2016-07-21$ & 207 & 3 & 3 & 218 \\
\hline Brier & solar & $2014-05-17$ & $2014-07-22$ & 208 & 1 & 1 & 64 \\
\hline Brier & solar & $2014-05-16$ & $2016-07-21$ & 209 & 3 & 3 & 177 \\
\hline Brier & solar & $2014-05-16$ & $2016-07-20$ & 210 & 3 & 3 & 165 \\
\hline Brier & solar & $2015-05-14$ & $2015-05-24$ & 211 & 1 & 0 & 11 \\
\hline Brier & solar & $2015-05-14$ & $2015-05-24$ & 212 & 1 & 0 & 11 \\
\hline Brier & battery & $2014-05-16$ & $2014-06-05$ & 213 & 1 & 0 & 21 \\
\hline Brier & battery & $2014-05-16$ & $2014-06-04$ & 214 & 1 & 0 & 20 \\
\hline Brier & battery & $2014-05-16$ & $2014-05-25$ & 215 & 1 & 0 & 10 \\
\hline Brier & battery & $2014-05-16$ & $2014-06-05$ & 216 & 1 & 0 & 21 \\
\hline Brier & battery & $2014-05-16$ & $2014-06-06$ & 217 & 1 & 0 & 22 \\
\hline Kent & solar & $2015-06-07$ & $2016-07-26$ & 317 & 2 & 2 & 121 \\
\hline Kent & solar & $2015-06-08$ & $2016-07-28$ & 318 & 2 & 2 & 126 \\
\hline Kent & solar & $2015-06-07$ & $2016-07-28$ & 319 & 2 & 2 & 135 \\
\hline Kent & solar & $2015-06-08$ & $2015-07-18$ & 320 & 1 & 1 & 34 \\
\hline Kent & solar & $2015-06-07$ & $2016-07-27$ & 321 & 2 & 2 & 106 \\
\hline Kent & solar & $2015-06-07$ & $2016-07-27$ & 322 & 2 & 2 & 133 \\
\hline Kent & solar & $2015-06-07$ & $2016-07-27$ & 323 & 2 & 2 & 134 \\
\hline Kent & solar & $2015-06-07$ & $2016-07-27$ & 324 & 2 & 2 & 99 \\
\hline Kent & solar & $2015-06-07$ & $2016-07-27$ & 325 & 2 & 2 & 136 \\
\hline Kent & solar & $2015-06-07$ & $2016-07-26$ & 326 & 2 & 2 & 129 \\
\hline Kent & solar & $2015-06-07$ & $2016-07-25$ & 330 & 2 & 2 & 95 \\
\hline & & & & & & & \\
\hline
\end{tabular}


Supplementary Figure 1. The following figure compliments Fig. 4 in the main article but uses stable-isotope results from analysis of feather samples instead of blood samples. Estimation of the relative importance of various wild and anthropogenic food resources available to Herring Gulls (Larus argentatus) captured on (a) Brier Island, NS, Canada and (b) Kent Island, NB, Canada, during the breeding seasons May-Jul. 2014-2016. Along the top of the table, the mean estimates (\%) of the proportion of diet that is comprised of each of 5 prey type categories are the results from a separate stable-isotope analysis (Table 4 feather estimates). Along the left-hand side of the table, the mean estimates (\%) of GPS points that were assigned to each of 6 prey source categories are the results from a separate GPS analysis (Table 2). Each score in the middle of the table is the average between a prey type category (top of table) and a prey source category (left-hand side of table); ecologically illogical prey source - prey type combinations are labelled as such. Scores can be used to objectively weigh the importance of specific wild (green cells) or anthropogenic (yellow cells) resources relative to other resources available to gulls. Higher resource use scores (darker-colored cells) indicate that gulls consumed high levels of a prey type that is obtained from a habitat type where gulls spent a lot of time foraging, therefore giving greater confidence that a particular wild or anthropogenic resource is an important part of gull diet.

Prey type - What do gulls eat?

Mean estimate (\%): stable-isotope (Table 4)

$\begin{array}{ccccc}\text { Mink } & \text { Industrial } & \text { Crab } & \text { High Trophic } & \text { Low Trophic } \\ & \text { Discards } & \text { Marine } & \text { Marine } \\ \text { Mink } & \text { Fisheries waste, } & \text { Green/Jonah } & \text { Fish, gull } & \text { Bivalves, krill, } \\ \text { feed/carcass } & \text { compost } & \text { crab } & \text { egg/carcass } & \text { amphipods }\end{array}$

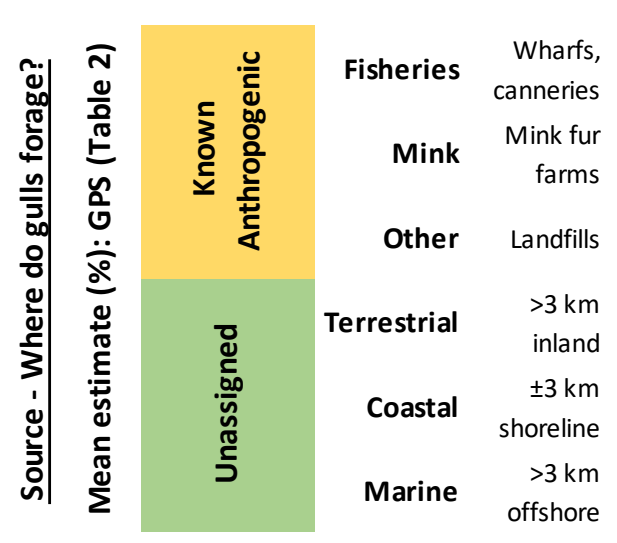

\begin{tabular}{|c|c|c|c|c|c|}
\hline & 12 & 17 & 25 & 29 & 18 \\
\hline 23 & illogical & 20 & 24 & 26 & 20 \\
\hline 37 & 25 & illogical & illogical & illogical & illogical \\
\hline 0 & illogical & 9 & illogical & illogical & illogical \\
\hline 6 & 9 & 12 & illogical & illogical & illogical \\
\hline 28 & illogical & 22 & 26 & 28 & 23 \\
\hline 5 & illogical & 11 & illogical & 17 & 12 \\
\hline
\end{tabular}


b.

Kent Island colony, NB, Canada
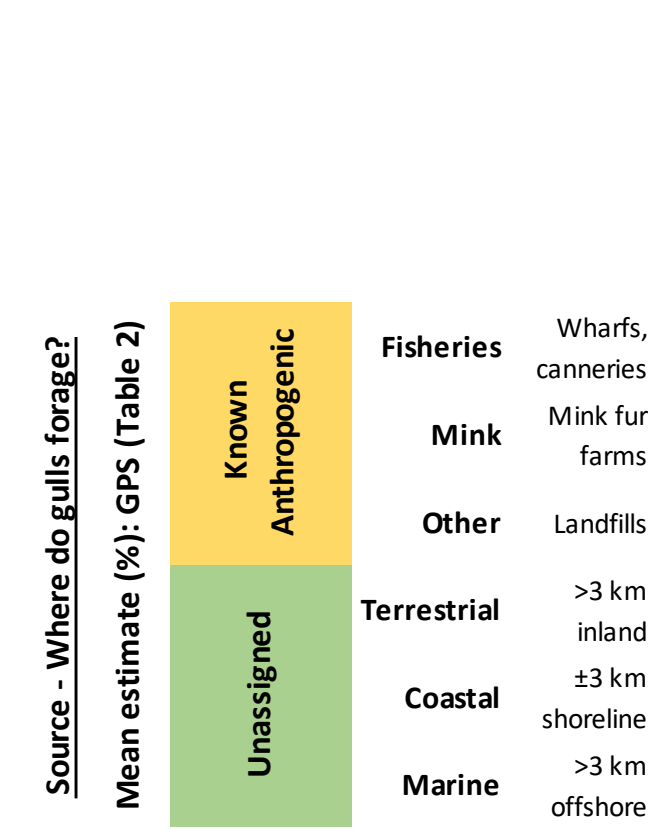

\section{Prey type - What do gulls eat?}

Mean estimate (\%): stable-isotope (Table 4)

$\begin{array}{ccccc}\text { Mink } & \begin{array}{c}\text { Industrial } \\ \text { Discards }\end{array} & \text { Crab } & \begin{array}{c}\text { High Trophic } \\ \text { Marine }\end{array} & \begin{array}{c}\text { Low Trophic } \\ \text { Marine }\end{array} \\ \text { Mink } & \text { Fisheries waste, } & \text { Green/Jonah } & \text { Fish, gull } & \text { Bivalves, krill, } \\ \text { feed/carcass } & \text { compost } & \text { crab } & \text { egg/carcass } & \text { amphipods }\end{array}$
8
9
49
22
12

\begin{tabular}{|c|c|c|c|c|c|}
\cline { 2 - 6 } 28 & illogical & 18 & 38 & 25 & 20 \\
\cline { 2 - 6 } & 6 & illogical & illogical & illogical & illogical \\
\cline { 2 - 6 } 1 & illogical & 5 & illogical & illogical & illogical \\
\hline 63 & 5 & 5 & illogical & illogical & illogical \\
\hline 5 & illogical & 36 & 56 & 42 & 37 \\
\hline
\end{tabular}

